\title{
NIST/NIH Vitamin D Metabolites Quality Assurance Program Report of Participant Results: Winter 2012 Comparability Study (Exercise 5)
}

Mary Bedner

Katrice A. Lippa

Susan S.-C. Tai 


\section{NIST/NIH Vitamin D Metabolites Quality Assurance Program Report of Participant Results: Winter 2012 Comparability Study (Exercise 5)}

Mary Bedner

Katrice A. Lippa

Susan S.-C. Tai

Chemical Sciences Division Material Measurement Laboratory

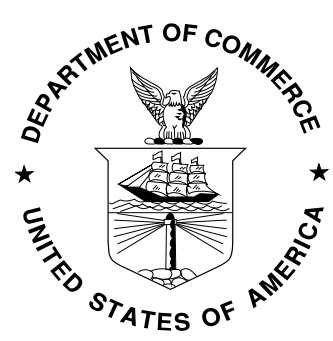

U.S. Department of Commerce Rebecca M. Blank, Acting Secretary

National Institute of Standards and Technology Patrick D. Gallagher, Under Secretary for Standards and Technology and Director 


\begin{abstract}
The National Institute of Standards and Technology (NIST) has established a Vitamin D Metabolites Quality Assurance Program (VitDQAP) in collaboration with the National Institutes of Health (NIH) Office of Dietary Supplements. Participants in the fifth exercise of this program, the Winter 2012 Comparability Study, were asked to use the methodology of their choice to measure concentrations of 25-hydroxyvitamin $\mathrm{D}$ in control and study materials distributed by NIST. The study materials consisted of SRM 1950 Metabolites in Human Plasma, SRM 972a Vitamin D Metabolites in Human Serum (Level 2), and SRM 968d Fat-Soluble Vitamins, Carotenoids and Cholesterol in Human Serum (Level 1). SRM 2972, which is comprised of separate ethanolic calibration solutions with known concentrations of $25(\mathrm{OH}) \mathrm{D}_{2}$ and $25(\mathrm{OH}) \mathrm{D}_{3}$, was provided as a control material. Participants provided their data to NIST, where it was compiled and evaluated for trueness relative to the NIST value and concordance within the participant community. A report of results was provided to all participants of the study, and laboratories were identified by code numbers known only to them. The results from this fifth study are reported along with a summary of the analytical methods used.
\end{abstract}




\section{OVERVIEW OF THE WINTER 2012 COMPARABILITY STUDY}

For the Winter 2012 Comparability Study of VitDQAP (Exercise 5), control and human serum study samples were distributed to participants for evaluation. SRM 2972, which is comprised of separate ethanolic solutions with known concentrations of 25-hydroxyvitamin $\mathrm{D}_{2}\left(25(\mathrm{OH}) \mathrm{D}_{2}\right)$ and 25-hydroxyvitamin $\mathrm{D}_{3}\left(25(\mathrm{OH}) \mathrm{D}_{3}\right)$, was provided as a control material for assay calibration or verification. Participants were asked to provide single results for each of these solutions. In addition, participants were asked to determine concentration values for $25(\mathrm{OH}) \mathrm{D}_{2}, 25(\mathrm{OH}) \mathrm{D}_{3}$, and a total concentration of 25-hydroxyvitamin $\mathrm{D}\left(25(\mathrm{OH}) \mathrm{D}_{\text {Total }}=25(\mathrm{OH}) \mathrm{D}_{2}+25(\mathrm{OH}) \mathrm{D}_{3}\right)$ for each of four samples (vials A, B, C, and D) of human plasma or serum (study materials). In this study, vial A was SRM 1950 Metabolites in Human Plasma, vials B and D were duplicate samples of SRM 972a Vitamin D Metabolites in Human Serum Level 2 (SRM 972a L2), and vial C was SRM 968d Fat-Soluble Vitamins, Carotenoids and Cholesterol in Human Serum Level 1 (SRM 968d L1). All materials consisted of blended human plasma or serum pools with endogenous 25(OH)D levels.

There were a total of 51 participants and 57 datasets (six participants provided data for two different methods) in the Winter 2012 study. Seventeen of the datasets originated from immunoassay (IA) techniques, including three from enzyme immunoassay (EIA), eight from chemiluminescence immunoassay (CLIA), and six from radioimmunoassay (RIA). Appendix A-1 summarizes the immunoassay methods used by the participants. Forty of the datasets originated from liquid chromatographic (LC) methods; of those, 32 were from LC with tandem mass spectrometric detection (LC-MS/MS), one was from LC-MS (orbitrap), and seven were from LC with ultraviolet absorbance detection (LC-UV). A summary of the LC methods used by the participants may be found in Appendices A-2 and A-3. From here, LC-MS/MS and LC-MS are collectively referred to as LC-MS ${ }^{\mathrm{n}}$.

The raw data received from all participants are summarized in Appendix B. All datasets from the immunoassay methods reported single values for $25(\mathrm{OH}) \mathrm{D}_{\text {Total }}$ in SRM 1950, SRM 972a L2, and SRM 968d L1. LC participants provided values for $25(\mathrm{OH}) \mathrm{D}_{2}, 25(\mathrm{OH}) \mathrm{D}_{3}$, as well as $25(\mathrm{OH}) \mathrm{D}_{\text {Total }}$ in SRM 1950, SRM 972a L2, and SRM 968d L1. Both LC and immunoassay datasets provided individual values for $25(\mathrm{OH}) \mathrm{D}_{2}$ and $25(\mathrm{OH}) \mathrm{D}_{3}$ in the ethanolic controls because the analytes were in separate solutions.

SRM 1950, SRM 972a L2, and SRM 968d L1 contain low levels of 25(OH) $\mathrm{D}_{2}$ (reported participant values ranging from $0.2 \mathrm{ng} / \mathrm{mL}$ to $1.7 \mathrm{ng} / \mathrm{mL}$ ), and most of the LC labs indicated this analyte was below their quantitation limit of $<1 \mathrm{ng} / \mathrm{mL}$ to $<7 \mathrm{ng} / \mathrm{mL}$. Therefore, the $25(\mathrm{OH}) \mathrm{D}_{\text {Total }}$ values reported in Appendix B are the same as the $25(\mathrm{OH}) \mathrm{D}_{3}$ values in the serum and plasma materials for the majority of LC participants.

Appendix B also provides the summarized results from the National Institute of Standards and Technology (NIST) for each of the serum materials. The $25(\mathrm{OH}) \mathrm{D}_{2}$ in SRM $968 \mathrm{~d} \mathrm{~L} 1$ was below the quantitation limit $(\approx 0.5 \mathrm{ng} / \mathrm{mL})$ for the NIST method. 


\section{WINTER 2012 COMPARABILITY STUDY RESULTS AND DISCUSSION}

\section{5(OH)D $D_{2}$ and $25(\mathrm{OH}) D_{3}$ in the control solutions (SRM 2972)}

Participants were asked to analyze the control materials to qualify their assays prior to measuring the study materials. A summary of the individual participant data for $25(\mathrm{OH}) \mathrm{D}_{2}$ and $25(\mathrm{OH}) \mathrm{D}_{3}$ in the SRM 2972 control solutions is provided in Table 1. Of the 57 datasets received for the Winter 2012 study, only 36 reported values for the ethanolic controls; of those, three were from immunoassay methods and 33 were from LC methods. Overall, the control solutions appeared more compatible with the LC methods, and several of the immunoassay participants reported that the calibration solutions were not compatible with their method and did not provide values.

The community results are summarized at the bottom of Table 1 for all reported methods, the LC methods only, and the LC-MS ${ }^{\mathrm{n}}$ methods only. The community results include the total number of quantitative values reported $(\mathrm{N})$, the median value for each analyte, the MADe (the median absolute deviation estimate, a robust estimate of the standard deviation), and the percent coefficient of variation (CV\%). The consensus results using robust statistics (i.e., median and MADe) were not calculated for the data from the IA methods because of the limited number of data reported.

The control materials were characterized at NIST using both gravimetry and LC-MS. Table 1 presents the NIST certified values with expanded uncertainties corresponding to 95\% confidence for SRM 2972. Participants were provided these values both on the shipping package and within the data reporting sheet so that they could qualify their methods prior to analyzing the study samples. 
Table 1. Summary of participant data and community results for $25(\mathrm{OH}) \mathrm{D}_{2}(\mathrm{ng} / \mathrm{mL})$ and $25(\mathrm{OH}) \mathrm{D}_{3}(\mathrm{ng} / \mathrm{mL})$ in the SRM 2972 control solutions.

\begin{tabular}{|c|c|c|}
\hline & & $\begin{array}{l}\text { SRM } 2972 \\
25(\mathrm{OH}) \mathrm{D}_{2}\end{array}$ \\
\hline Lab & Method & Value \\
\hline 056 & LC-MS/MS & 230.6 \\
\hline 060 & LC-MS/MS & $n / r$ \\
\hline 062 & RIA & $\mathrm{n} / \mathrm{r}$ \\
\hline 110 & LC-UV & 237.1 \\
\hline 116 & LC-MS/MS & 245.1 \\
\hline 119 & LC-MS & 182.4 \\
\hline 124 & LC-MS/MS & 47.0 \\
\hline 139 & LC-UV & 239.7 \\
\hline $160 a$ & LC-MS/MS & 170.0 \\
\hline 184 & LC-MS/MS & 240.5 \\
\hline $185 a$ & LC-MS/MS & 238.6 \\
\hline 186 & LC-MS/MS & 238.0 \\
\hline 194 & LC-MS/MS & 240.5 \\
\hline 195 & LC-MS/MS & 241.0 \\
\hline 196 & CLIA & 198.6 \\
\hline 197 & LC-MS/MS & 234.0 \\
\hline $198 a$ & LC-MS/MS & 207.4 \\
\hline 199 & LC-MS/MS & 245.0 \\
\hline 200 & RIA & 278.1 \\
\hline 202 & LC-MS/MS & 241.5 \\
\hline 209 & LC-MS/MS & 248.7 \\
\hline $210 a$ & RIA & 230.0 \\
\hline 211 & LC-MS/MS & 240.4 \\
\hline 212 & LC-MS/MS & 231.5 \\
\hline 216 & LC-MS/MS & 258.0 \\
\hline 217 & LC-MS/MS & 233.8 \\
\hline $218 b$ & LC-MS/MS & 240.9 \\
\hline $221 a$ & LC-MS/MS & 249.7 \\
\hline 223 & LC-MS/MS & 241.2 \\
\hline 225 & LC-MS/MS & 235.9 \\
\hline $228 a$ & LC-MS/MS & 240.0 \\
\hline 231 & LC-UV & 268.7 \\
\hline 234 & LC-MS/MS & 246.0 \\
\hline 241 & LC-MS/MS & 212.0 \\
\hline 242 & LC-MS/MS & 245.0 \\
\hline 243 & LC-UV & 245.9 \\
\hline 244 & LC-MS/MS & 222.0 \\
\hline 245 & LC-UV & 240.8 \\
\hline n) & $\mathrm{N}$ & 36 \\
\hline$=8$ & Median & 240.2 \\
\hline$<\bar{\theta}$ & MADe & 8.5 \\
\hline & CV\% & 3.5 \\
\hline & $\mathrm{N}$ & 33 \\
\hline 08 & Median & 240.4 \\
\hline ב & MADe & 7.0 \\
\hline & CV\% & 2.9 \\
\hline & $\mathrm{N}$ & 28 \\
\hline$\stackrel{0}{5}$ & Median & 240.2 \\
\hline jù & MADe & 8.0 \\
\hline & CV\% & 3.3 \\
\hline & NIST Value & 238.6 \\
\hline & $U_{95}$ & 3.9 \\
\hline
\end{tabular}

\begin{tabular}{|c|c|c|}
\hline & & $\begin{array}{l}\text { SRM } 2972 \\
25(\mathrm{OH}) \mathrm{D} 3\end{array}$ \\
\hline Lab & Method & Value \\
\hline 056 & LC-MS/MS & 342.4 \\
\hline 060 & LC-MS/MS & 372.0 \\
\hline 062 & RIA & 323.1 \\
\hline 110 & LC-UV & 334.1 \\
\hline 116 & LC-MS/MS & 334.6 \\
\hline 119 & LC-MS & 343.4 \\
\hline 124 & LC-MS/MS & 123.0 \\
\hline 139 & LC-UV & 328.5 \\
\hline $160 a$ & LC-MS/MS & 281.0 \\
\hline 184 & LC-MS/MS & 336.5 \\
\hline $185 a$ & LC-MS/MS & 334.8 \\
\hline 186 & LC-MS/MS & 335.0 \\
\hline 194 & LC-MS/MS & 330.5 \\
\hline 195 & LC-MS/MS & 333.0 \\
\hline 196 & CLIA & 298.8 \\
\hline 197 & LC-MS/MS & 336.0 \\
\hline $198 a$ & LC-MS/MS & 327.1 \\
\hline 199 & LC-MS/MS & 349.0 \\
\hline 200 & RIA & 386.9 \\
\hline 202 & LC-MS/MS & 339.0 \\
\hline 209 & LC-MS/MS & 336.7 \\
\hline $210 a$ & RIA & 294.3 \\
\hline 211 & LC-MS/MS & 328.1 \\
\hline 212 & LC-MS/MS & 330.9 \\
\hline 216 & LC-MS/MS & 333.0 \\
\hline 217 & LC-MS/MS & 358.1 \\
\hline $218 b$ & LC-MS/MS & 333.9 \\
\hline $221 a$ & LC-MS/MS & 357.8 \\
\hline 223 & LC-MS/MS & 313.2 \\
\hline 225 & LC-MS/MS & 284.1 \\
\hline $228 a$ & LC-MS/MS & 334.0 \\
\hline 231 & LC-UV & 287.3 \\
\hline 234 & LC-MS/MS & 300.0 \\
\hline 241 & LC-MS/MS & 302.5 \\
\hline 242 & LC-MS/MS & 332.0 \\
\hline 243 & LC-UV & 325.6 \\
\hline 244 & LC-MS/MS & 337.0 \\
\hline 245 & LC-UV & 335.5 \\
\hline & & 38 \\
\hline & Median & 333.5 \\
\hline & MADe & 8.8 \\
\hline & CV\% & 2.6 \\
\hline & $N$ & 34 \\
\hline & Median & 334.0 \\
\hline & MADe & 7.8 \\
\hline & CV\% & 2.3 \\
\hline & $N$ & 29 \\
\hline & Median & 334.0 \\
\hline & MADe & 7.4 \\
\hline & CV\% & 2.2 \\
\hline & NIST Value & 334.0 \\
\hline & $U_{95}$ & 5.2 \\
\hline
\end{tabular}


For all participant datasets, the single data values reported for $25(\mathrm{OH}) \mathrm{D}_{2}$ and $25(\mathrm{OH}) \mathrm{D}_{3}$ in the control solutions, SRM 2972, are plotted in Figure 1. The results from immunoassay methods are displayed with closed red circles (๑), and the results from the LC-based methods are displayed with closed black squares ( $\mathbf{\square})$.

From the single reported values for all LC datasets, the consensus median and the consensus variability ( $2 \times$ MADe) were determined (reported in Table 1). In Figure 1, the solid lines ( $\longrightarrow)$ represent the consensus median and the dashed lines (- - - -) represent the approximate 95\% confidence interval $(2 \times$ MADe) for the LC datasets; the laboratories with results that fall between the two dashed lines are within the consensus variability.

The grey-shaded bar in Figure 1 represents the interval in which NIST believes the "true value" exists for these solutions (i.e., NIST value \pm approximately $95 \%$ confidence intervals $\left(U_{95}\right)$ ). The consensus median value for the LC methods lies within the NIST expanded uncertainty range for both $25(\mathrm{OH}) \mathrm{D}_{2}$ and $25(\mathrm{OH}) \mathrm{D}_{3}$. 
Figure 1. 25(OH) $\mathrm{D}_{2}$ and $25(\mathrm{OH}) \mathrm{D}_{3}$ values in SRM 2972 for immunoassay and LC methods. The grey-shaded bars represent the ranges bound by the NIST certified values with $\pm U_{95}$ expanded uncertainty.
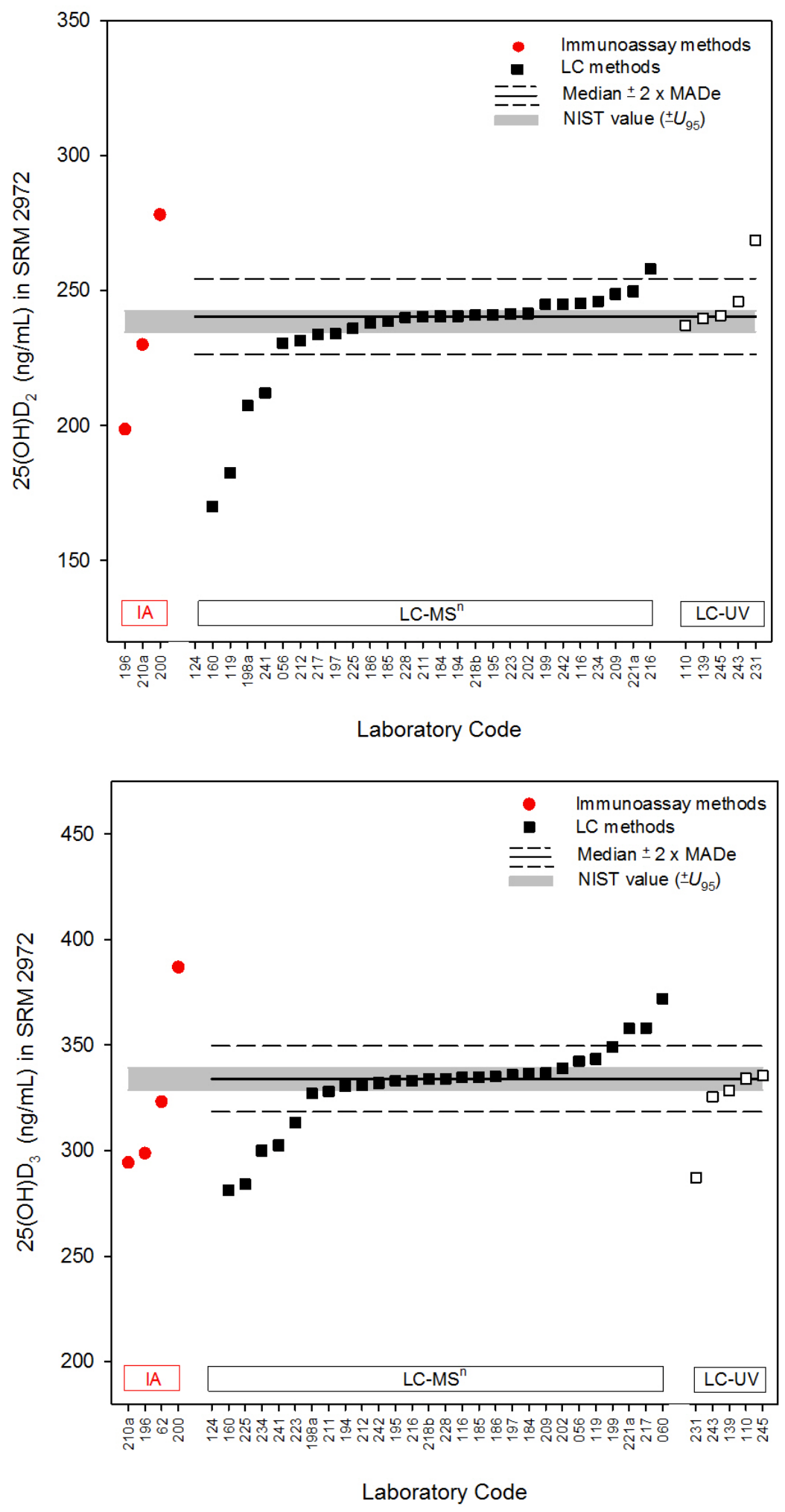


\section{5(OH)D in SRM 1950, SRM 972a L2, and SRM 968d L1}

A summary of the individual participant data for $25(\mathrm{OH}) \mathrm{D}_{\text {Total }}$ in samples SRM 1950 (vial A), SRM 972a L2 (vials B \& D), and SRM 968d L1 (vial C) is provided in Table 2. The summarized data also include the mean, standard deviation (SD), and percent relative standard deviation (\%rSD) of the two reported values for SRM 972a L2.

The community results are summarized at the bottom of the table for all reported methods, the immunoassay methods only, the LC methods only, and the LC-MS ${ }^{\mathrm{n}}$ methods only. These summarized results include $\mathrm{N}$, the median value, the MADe, and the $\mathrm{CV} \%$.

Table 2 also presents the NIST results with approximated 95\% confidence limits $\left(U_{95}\right)$ obtained for the three study materials.

For SRM 1950, 25(OH)D $\mathrm{D}_{\text {Total }}$ is the sum of the NIST certified and reference values for $25(\mathrm{OH}) \mathrm{D}_{3}$ and $25(\mathrm{OH}) \mathrm{D}_{2}$, respectively, and the $95 \%$ confidence limit $\left(U_{95}\right)$ was approximated using the individual uncertainties reported for the two analytes. Details about the NIST methods and measurements are reported in the Certificate of Analysis for SRM $1950^{\mathrm{a}}$.

For SRM 972a L2, the NIST result for $25(\mathrm{OH}) \mathrm{D}_{\text {Total }}$ is the sum of the certified values for $25(\mathrm{OH}) \mathrm{D}_{3}$ and $25(\mathrm{OH}) \mathrm{D}_{2}$, and the $95 \%$ confidence limit $\left(U_{95}\right)$ incorporates the uncertainties for the two analytes. For SRM 968d L1, the NIST value for $25(\mathrm{OH}) \mathrm{D}_{3}$ was obtained using an LC-MS/MS reference measurement procedure ${ }^{\mathrm{b}}$ recognized by the Joint Committee for Traceability in Laboratory Medicine (JCTLM), and the $U_{95}$ confidence interval includes components for both measurement variability $(\mathrm{N}=8)$ and measurement uncertainty associated with the density. The $25(\mathrm{OH}) \mathrm{D}_{2}$ was below the quantitation limit $(\approx 0.5 \mathrm{ng} / \mathrm{mL})$ in SRM 968d L1 and was not included in the results for $25(\mathrm{OH}) \mathrm{D}_{\text {Total }}$.

\footnotetext{
${ }^{a}$ https://www-s.nist.gov/srmors/view_cert.cfm?srm=1950

b Tai, S. S.-C., Bedner, M. and Phinney, K.W. Anal. Chem. 2010 82, 1942-1948.
} 
Table 2. Summary of participant data for $25(\mathrm{OH}) \mathrm{D}_{\text {Total }}(\mathrm{ng} / \mathrm{mL})$ in SRM 1950, SRM 972a L2, and SRM 968d L1.

\begin{tabular}{|c|c|}
\hline Lab & Method \\
\hline 017 & CLIA \\
\hline 026 & LC-MS/MS \\
\hline 056 & LC-MS/MS \\
\hline 060 & LC-MS/MS \\
\hline 062 & RIA \\
\hline $086 a$ & CLIA \\
\hline $086 b$ & RIA \\
\hline 110 & LC-UV \\
\hline 116 & LC-MS/MS \\
\hline 119 & LC-MS \\
\hline 124 & LC-MS/MS \\
\hline 139 & LC-UV \\
\hline $160 a$ & LC-MS/MS \\
\hline 161 & CLIA \\
\hline 180 & RIA \\
\hline 184 & LC-MS/MS \\
\hline $185 a$ & LC-MS/MS \\
\hline $185 b$ & CLIA \\
\hline 186 & LC-MS/MS \\
\hline 188 & CLIA \\
\hline 189 & LC-UV \\
\hline 191 & RIA \\
\hline 194 & LC-MS/MS \\
\hline 195 & LC-MS/MS \\
\hline 196 & CLIA \\
\hline 197 & LC-MS/MS \\
\hline $198 a$ & LC-MS/MS \\
\hline $198 \mathrm{~b}$ & EIA \\
\hline 199 & LC-MS/MS \\
\hline 200 & RIA \\
\hline 201 & EIA \\
\hline 202 & LC-MS/MS \\
\hline 209 & LC-MS/MS \\
\hline $210 a$ & RIA \\
\hline $210 \mathrm{~b}$ & CLIA \\
\hline 211 & LC-MS/MS \\
\hline 212 & LC-MS/MS \\
\hline 215 & LC-MS/MS \\
\hline 216 & LC-MS/MS \\
\hline 217 & LC-MS/MS \\
\hline $218 a$ & CLIA \\
\hline $218 \mathrm{~b}$ & LC-MS/MS \\
\hline 219 & LC-MS/MS \\
\hline 220 & LC-MS/MS \\
\hline $221 a$ & LC-MS/MS \\
\hline $221 b$ & LC-UV \\
\hline 223 & LC-MS/MS \\
\hline 225 & LC-MS/MS \\
\hline $228 a$ & LC-MS/MS \\
\hline 231 & LC-UV \\
\hline 234 & LC-MS/MS \\
\hline 236 & CLIA \\
\hline 241 & LC-MS/MS \\
\hline 242 & LC-MS/MS \\
\hline 243 & LC-UV \\
\hline 244 & LC-MS/MS \\
\hline 245 & LC-UV \\
\hline$=\frac{\stackrel{n}{0}}{\bar{\Sigma}}$ & $\begin{array}{r}\mathrm{N} \\
\text { Median } \\
\text { MADe } \\
\text { CV\% }\end{array}$ \\
\hline$\leq \frac{\frac{n}{0}}{\frac{D}{0}}$ & $\begin{array}{r}\mathrm{N} \\
\text { Median } \\
\text { MADe } \\
\text { CV\% }\end{array}$ \\
\hline U. & $\begin{array}{r}\mathrm{N} \\
\text { Median } \\
\text { MADe } \\
\text { CV\% }\end{array}$ \\
\hline$\sum_{j}^{n}$ & $\begin{array}{r}\mathrm{N} \\
\text { Median } \\
\text { MADe } \\
\text { CV\% }\end{array}$ \\
\hline
\end{tabular}

\begin{tabular}{|c|c|c|c|c|c|c|}
\hline SRM 1950 & SRM 972a L2 & SRM 968d L1 & SRM 972a L2 & \multicolumn{3}{|c|}{ SRM 972a L2 Combined } \\
\hline Vial A & Vial B & Vial C & Vial D & Mean & SD & \%RSD \\
\hline 24.5 & 19.2 & 13.7 & 17.9 & 18.5 & 0.9 & 5.0 \\
\hline 29.1 & 20.6 & 13.9 & 21.1 & 20.9 & 0.4 & 1.7 \\
\hline 25.3 & 19.2 & 13.1 & 19.7 & 19.5 & 0.4 & 1.8 \\
\hline 33.9 & 22.4 & 15.1 & 22.1 & 22.3 & 0.2 & 1.0 \\
\hline 28.7 & 20.6 & 13.3 & 21.2 & 20.9 & 0.4 & 2.0 \\
\hline 32.9 & 21.6 & 14.5 & 23.3 & 22.5 & 1.2 & 5.4 \\
\hline 33.0 & 24.0 & 17.0 & 28.0 & 26.0 & 2.8 & 11 \\
\hline 24.4 & 19.9 & 38.9 & 17.9 & 18.9 & 1.4 & 7.5 \\
\hline 26.1 & 18.2 & 13.5 & 18.4 & 18.3 & 0.2 & 1.0 \\
\hline 25.5 & 18.0 & 12.9 & 17.8 & 17.9 & 0.1 & 0.8 \\
\hline 26.3 & 18.7 & 15.5 & 20.3 & 19.5 & 1.1 & 5.8 \\
\hline 29.6 & 23.0 & 22.1 & 21.8 & 22.4 & 0.8 & 3.8 \\
\hline 25.3 & 18.6 & 12.0 & 18.3 & 18.5 & 0.2 & 1.1 \\
\hline 26.7 & 19.9 & 17.0 & 18.5 & 19.2 & 1.0 & 5.2 \\
\hline 25.1 & 16.1 & 12.1 & 17.6 & 16.9 & 1.1 & 6.5 \\
\hline 28.7 & 20.1 & 13.6 & 17.5 & 18.8 & 1.8 & 9.8 \\
\hline 27.0 & 19.3 & 14.7 & 32.8 & 26.1 & 9.5 & 37 \\
\hline 33.3 & 21.5 & 13.8 & 20.2 & 20.9 & 0.9 & 4.4 \\
\hline 13.0 & 8.0 & 7.0 & 12.0 & 10.0 & 2.8 & 28 \\
\hline 31.5 & 21.8 & 16.2 & 19.1 & 20.5 & 1.9 & 9.3 \\
\hline 30.9 & 28.4 & 10.0 & 26.4 & 27.4 & 1.4 & 5.2 \\
\hline 27.5 & 18.5 & 14.4 & 19.0 & 18.8 & 0.3 & 1.8 \\
\hline 26.5 & 20.7 & 11.4 & 17.4 & 19.1 & 2.3 & 12 \\
\hline 26.3 & 18.7 & 11.8 & 18.3 & 18.5 & 0.3 & 1.5 \\
\hline 28.0 & 18.5 & 15.3 & 19.4 & 19.0 & 0.6 & 3.4 \\
\hline 28.0 & 19.0 & 14.0 & 19.0 & 19.0 & 0.0 & 0.0 \\
\hline 29.9 & 20.7 & 14.4 & 20.5 & 20.6 & 0.1 & 0.7 \\
\hline 31.6 & 20.3 & 15.3 & 20.2 & 20.3 & 0.1 & 0.3 \\
\hline 23.0 & 20.3 & 13.1 & 18.7 & 19.5 & 1.1 & 5.8 \\
\hline 25.8 & 18.9 & 14.6 & 18.8 & 18.9 & 0.1 & 0.4 \\
\hline 33.4 & 21.7 & 16.0 & 22.8 & 22.3 & 0.8 & 3.5 \\
\hline 27.2 & 21.9 & 14.1 & 20.6 & 21.3 & 0.9 & 4.3 \\
\hline 26.7 & 20.6 & 13.7 & 17.8 & 19.2 & 2.0 & 10 \\
\hline 26.8 & 22.1 & 15.1 & 19.6 & 20.8 & 1.8 & 8.7 \\
\hline 30.4 & 18.9 & 15.1 & 20.2 & 19.6 & 0.9 & 4.7 \\
\hline 26.9 & 18.7 & 13.1 & 18.7 & 18.7 & 0.0 & 0.0 \\
\hline 30.8 & 22.8 & 14.5 & 21.0 & 21.9 & 1.3 & 5.8 \\
\hline 24.0 & 20.4 & 12.0 & 20.0 & 20.2 & 0.3 & 1.4 \\
\hline 33.5 & 25.6 & 17.9 & 26.7 & 26.2 & 0.8 & 3.0 \\
\hline 24.8 & 19.6 & 13.6 & 19.2 & 19.4 & 0.3 & 1.5 \\
\hline 26.4 & 17.7 & 14.6 & 17.2 & 17.5 & 0.4 & 2.0 \\
\hline 27.2 & 24.9 & 18.3 & 27.2 & 26.1 & 1.6 & 6.2 \\
\hline 26.2 & 19.8 & 13.4 & 19.5 & 19.7 & 0.2 & 1.1 \\
\hline 28.0 & 22.0 & 15.0 & 21.0 & 21.5 & 0.7 & 3.3 \\
\hline 26.1 & 17.5 & 12.8 & 19.8 & 18.7 & 1.6 & 8.7 \\
\hline 25.3 & 15.9 & 51.0 & 20.6 & 18.3 & 3.3 & 18 \\
\hline 24.8 & 18.6 & 13.3 & 18.3 & 18.5 & 0.2 & 1.1 \\
\hline 32.4 & 24.8 & 20.1 & 21.1 & 23.0 & 2.6 & 11.4 \\
\hline 28.8 & 24.6 & 15.6 & 27.1 & 25.9 & 1.8 & 6.8 \\
\hline 30.6 & 20.8 & 45.7 & 21.0 & 20.9 & 0.1 & 0.7 \\
\hline 25.2 & 18.9 & 13.7 & 18.0 & 18.5 & 0.6 & 3.4 \\
\hline 27.8 & 17.4 & 12.5 & 17.9 & 17.7 & 0.4 & 2.0 \\
\hline 25.8 & 19.5 & 12.5 & 19.2 & 19.4 & 0.2 & 1.1 \\
\hline 28.3 & 20.5 & 14.5 & 20.6 & 20.6 & 0.1 & 0.3 \\
\hline 28.8 & 21.2 & 14.8 & 21.5 & 21.4 & 0.2 & 1.0 \\
\hline 27.0 & 18.0 & 14.0 & 18.0 & 18.0 & 0.0 & 0.0 \\
\hline 38.5 & 33.2 & 15.9 & 27.2 & 30.2 & 4.2 & 13.9 \\
\hline 57 & 57 & 57 & 57 & 57 & & \\
\hline 27.2 & 20.1 & 14.4 & 19.7 & 19.5 & & \\
\hline 2.8 & 2.2 & 1.6 & 2.1 & 1.8 & & \\
\hline 10 & 11 & 11 & 11 & 9.3 & & \\
\hline 17 & 17 & 17 & 17 & 17 & & \\
\hline 28.0 & 19.9 & 14.6 & 19.4 & 19.6 & & \\
\hline 3.6 & 2.4 & 1.2 & 1.3 & 1.9 & & \\
\hline 13 & 12 & 8 & 6.9 & 9.8 & & \\
\hline 40 & 40 & 40 & 40 & 40 & & \\
\hline 27.0 & 20.2 & 14.0 & 19.9 & 19.5 & & \\
\hline 2.5 & 2.2 & 1.6 & 2.3 & 1.7 & & \\
\hline 9.4 & 11 & 11 & 12 & 8.8 & & \\
\hline 33 & 33 & 33 & 33 & 33 & & \\
\hline 26.7 & 19.8 & 13.7 & 19.5 & 19.5 & & \\
\hline 2.1 & 1.6 & 1.2 & 1.8 & 1.5 & & \\
\hline 7.8 & 8.2 & 8.7 & 9.1 & 7.6 & & \\
\hline 25.3 & 18.9 & 12.4 & 18.9 & 18.9 & & \\
\hline 0.8 & 0.4 & 0.3 & 0.4 & 0.4 & & \\
\hline
\end{tabular}


For all participant datasets, the single reported values for 25(OH)D $\mathrm{D}_{\text {Total }}$ in SRM 1950 and SRM 968d L1, and the average reported values ( \pm 2 SD) for SRM 972a L2 are plotted in Figure 2. The results from immunoassay methods are displayed with closed red circles $(\bullet)$, and the results from the LCbased methods are displayed with closed black squares $(\boldsymbol{\square})$. Each figure also has a legend that indicates which individual methods were used to obtain the reported values: CLIA, EIA, RIA, LC$\mathrm{MS}^{\mathrm{n}}$, or LC-UV.

From the average values for all datasets for a given technique (IA or LC), the consensus median and the consensus variability ( $2 \times$ MADe) were determined (reported in Table 2 ). For each of the techniques within both graphs, the solid lines (-) represent the consensus median and the dashed lines (- - - -) represent the consensus variability $(2 \times$ MADe).

For the IA data for material SRM 1950, the consensus variability based on MADe is an overestimation of the 95\% confidence limits about the median. The non-Gaussian data distribution contributes to a relatively wide range for the central 50\% of this data, resulting in a large MADe (Figure 2). Since the consensus variability is not well-described with a MADe estimation, a meaningful assessment of the consensus range, the outlying results, and the agreement with the NIST value is hindered for the IA results for SRM 1950.

For the LC datasets for SRM 1950 and for both the LC and IA datasets for SRM 972a L2 and SRM 968d L1, the laboratories with results that fall between the two dashed lines are within the consensus variability area for their technique (IA or LC). The grey-shaded bar for each figure represents the NIST value and its associated uncertainty (i.e., value $\pm U_{95}$ ). NIST believes that the "true" value for each material lies within this interval. When this bar is not within the consensus range, then there may be method bias.

Specific results as assessed from Figure 2 are summarized below.

SRM 1950

- For the IA results, the data appear to be non-normally distributed, and the consensus variability is not well-described with a MADe estimation.

- For the LC results, all but five datasets are within the consensus variability range.

- The consensus median value for the IA results is higher than the consensus median value for the LC results; both LC and IA median values are higher than the NIST expanded uncertainty range (grey-shaded bar).

- The NIST expanded uncertainty range (grey-shaded bar) falls within the consensus variability range for $\mathrm{LC}$ and overlaps the IA data range

\section{SRM 972a L2}

- For the IA results, all but one dataset are within the consensus variability range when the average results are considered.

- For the LC results, all but seven datasets are within the consensus variability range when the average results are considered.

- The consensus median values are comparable for both the IA results and LC results and are slightly higher than the NIST expanded uncertainty range (grey-shaded bar). 
- The NIST expanded uncertainty range (grey-shaded bar) falls within the consensus variability ranges for both IA and LC.

\section{SRM 968d L1}

- For the IA results, all datasets are within the consensus variability range.

- For the LC results, nine datasets are outside of the consensus variability range (four LC-MS ${ }^{\mathrm{n}}$, five LC-UV).

- The consensus median value for the IA results is higher than the consensus median value for the LC results; both LC and IA median values are higher than the NIST expanded uncertainty range (grey-shaded bar).

- The NIST expanded uncertainty range (grey-shaded bar) falls within the consensus variability range for LC and overlaps the consensus variability range for IA.

Overall, the results for the three study materials are consistent, with the majority of the participant values higher than the NIST value. In addition, the consensus variability is similar but relatively high for the three materials, ranging from $9.3 \%$ to $11 \%$ when all methods are considered (Table 2). Similar trends have also been observed for many of the study materials evaluated in previous studies of the VitDQAP. A goal of the program is to achieve better agreement between the participant consensus median value and the NIST value and to better understand the sources of bias between the results. In addition, a major goal of VitDQAP is to reduce the consensus variability to better represent the community's measurement capability while also recognizing that a "fit-forpurpose" variability level may exist.

It is notable that the NIST method separates $25(\mathrm{OH}) \mathrm{D}_{3}$ and its 3-epimer, 3-epi-25(OH) $\mathrm{D}_{3}$, which was detected in all study materials but quantitated in SRM 972a L2 only $(1.29 \mathrm{ng} / \mathrm{mL} \pm$ $0.06 \mathrm{ng} / \mathrm{mL})$. The 3-epi-25(OH) $\mathrm{D}_{3}$ coelutes with $25(\mathrm{OH}) \mathrm{D}_{3}$ using typical chromatographic columns (C8, C18) and is detected by the same multiple reaction monitoring (MRM) ions in MS/MS and absorbance wavelength in UV, leading to a potential bias for LC-based methods. One of the LC-MS/MS participants (number 56) noted using a method that separates 3-epi-25(OH) $\mathrm{D}_{3}$ and provided values for this analyte that ranged from $\approx 3 \%$ to $\approx 6 \%$ of $25(\mathrm{OH}) \mathrm{D}_{\text {Total }}$ in the study materials. However, the $25(\mathrm{OH}) \mathrm{D}_{3}$ values reported by LC participants that use $\mathrm{C} 8$ and $\mathrm{C} 18$ columns represent the sum of $25(\mathrm{OH}) \mathrm{D}_{3}$ and 3-epi-25(OH) $\mathrm{D}_{3}$, and $25(\mathrm{OH}) \mathrm{D}_{\text {Total }}$ also includes a contribution from 3-epi-25(OH) $\mathrm{D}_{3}$. It is unclear how the presence of 3-epi-25(OH) $\mathrm{D}_{3}$ affects the $25(\mathrm{OH}) \mathrm{D}_{\text {Total }}$ for immunoassay results. 
Figure 2. Plots of the single reported values for $25(\mathrm{OH}) \mathrm{D}_{\text {Total }}$ in SRM 1950 and SRM 968d L1, and the average reported values ( $\pm 2 \mathrm{SD}$ ) for SRM 972a L2 as determined by immunoassay (CLIA, EIA and RIA) and LC (LC-MS ${ }^{\mathrm{n}}$ and LC-UV) methods. The grey-shaded bars represent the ranges bound by the NIST values with \pm estimated $U_{95}$ uncertainty.
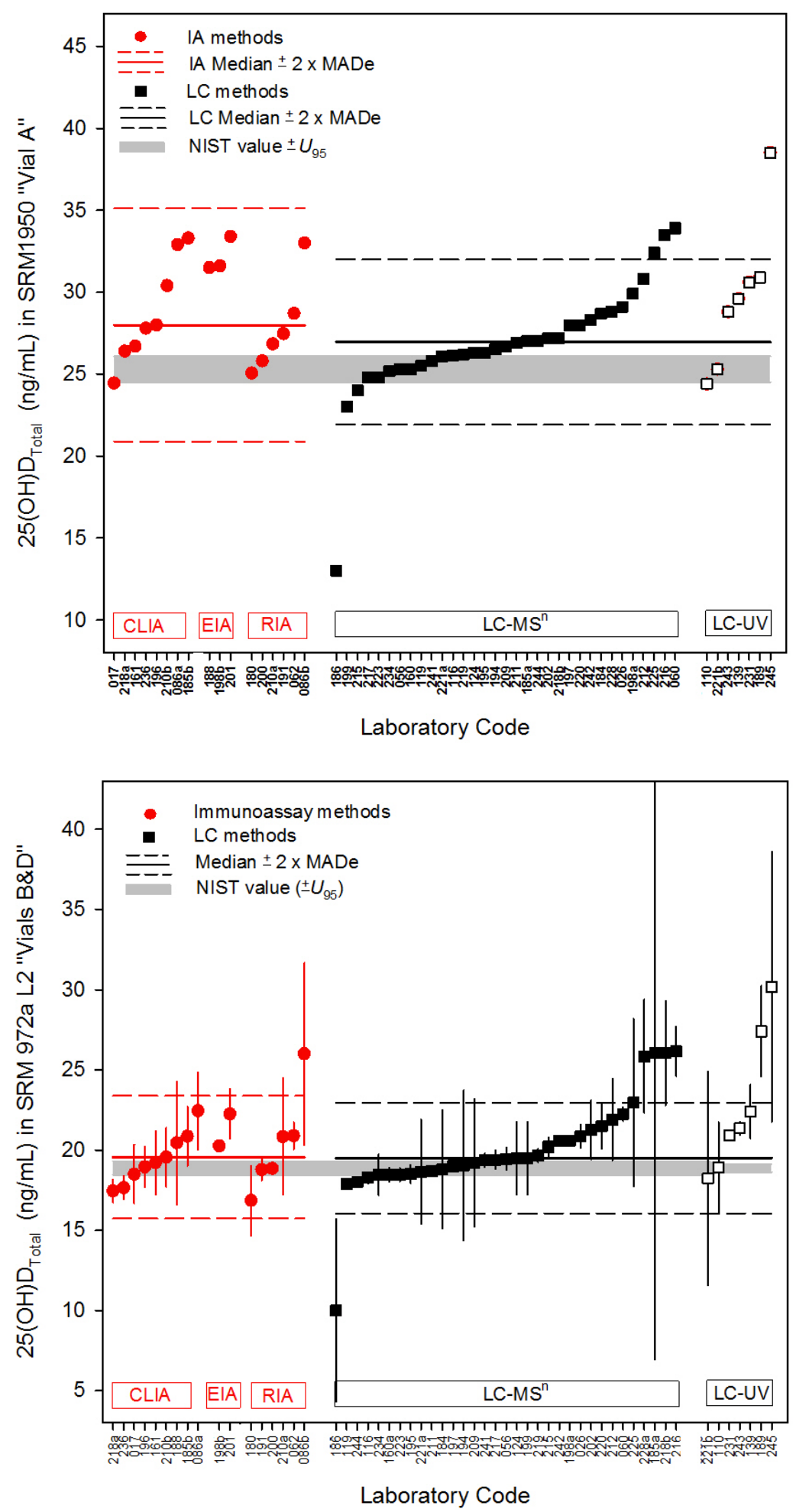
Figure 2 (cont'd). Plots of the single reported values for 25(OH)D Total in SRM 1950 and SRM 968d L1, and the average reported values ( \pm 2 SD) for SRM 972a L2 as determined by immunoassay (CLIA, EIA and RIA) and LC (LC-MS ${ }^{\mathrm{n}}$ and LC-UV) methods. The grey-shaded bars represent the ranges bound by the NIST values with \pm estimated $U_{95}$ uncertainty.

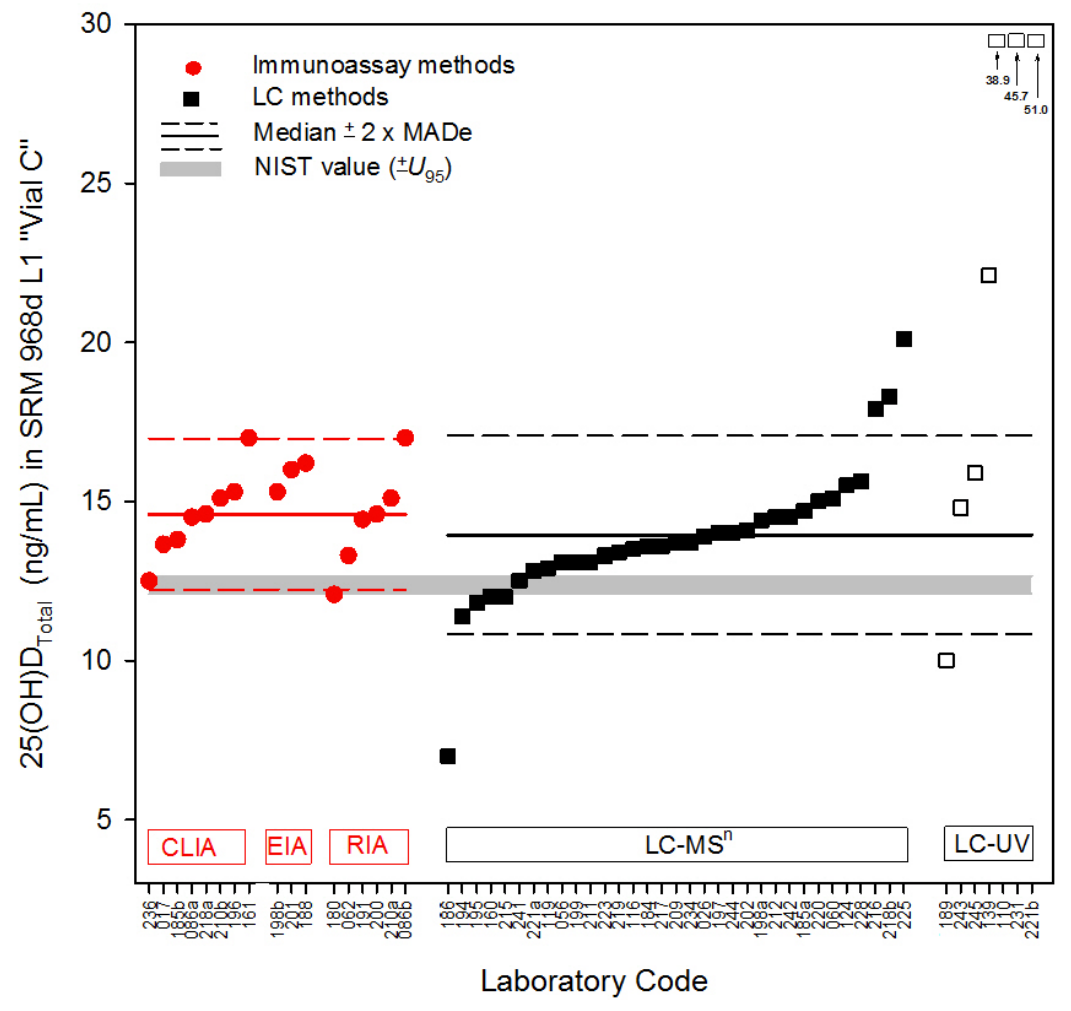


Figure 3 is a direct graphical comparison of the 25(OH)D results for the duplicate samples of SRM 972a L2 (vial B and vial D). For the first Youden plot (Panel A), there are two blue consensus boxes, one for IA methods and one for LC methods (as indicated). Laboratory results that are within the consensus range for both study materials are within the blue consensus boxes. Conversely, laboratory results that fall outside of (or on the edge of) either of the consensus boxes are not included in the consensus ranges and are highlighted with their laboratory code numbers (numbers 186, 180, 225, 245, 189, 216, 218b, 228, 086b and 185a). The NIST value for this material $(18.9 \mathrm{ng} / \mathrm{mL})$ is denoted with a red diamond symbol $(\diamond)$, and the Youden line $(\mathrm{y}=\mathrm{x})$ centered on the NIST value is illustrated by a red line (-) across the magnitude of the $y$ - and $x$ axis, respectively. The Youden line runs through both the IA and LC consensus boxes for these materials.

For the second Youden plot (Panel B), the results for SRM 972a L2 are evaluated with respect to a $10 \%$ range relative to the NIST value for this material $(18.9 \mathrm{ng} / \mathrm{mL})$. Laboratory results that fall outside of this range are indicative of non-repeatable measurement performance for this material and are highlighted with their laboratory code numbers (numbers 186, 221b, 194, 209, 184, 225, 245, 086b and 185a). In general, the combined results for vial B and vial D from these laboratories had a relative standard deviation $\geq 10 \%$ (Table 2 ). The relative distance of the individual laboratory results from the Youden line $(\mathrm{y}=\mathrm{x})$ is also indicative of the relative level of imprecision between the two results. 

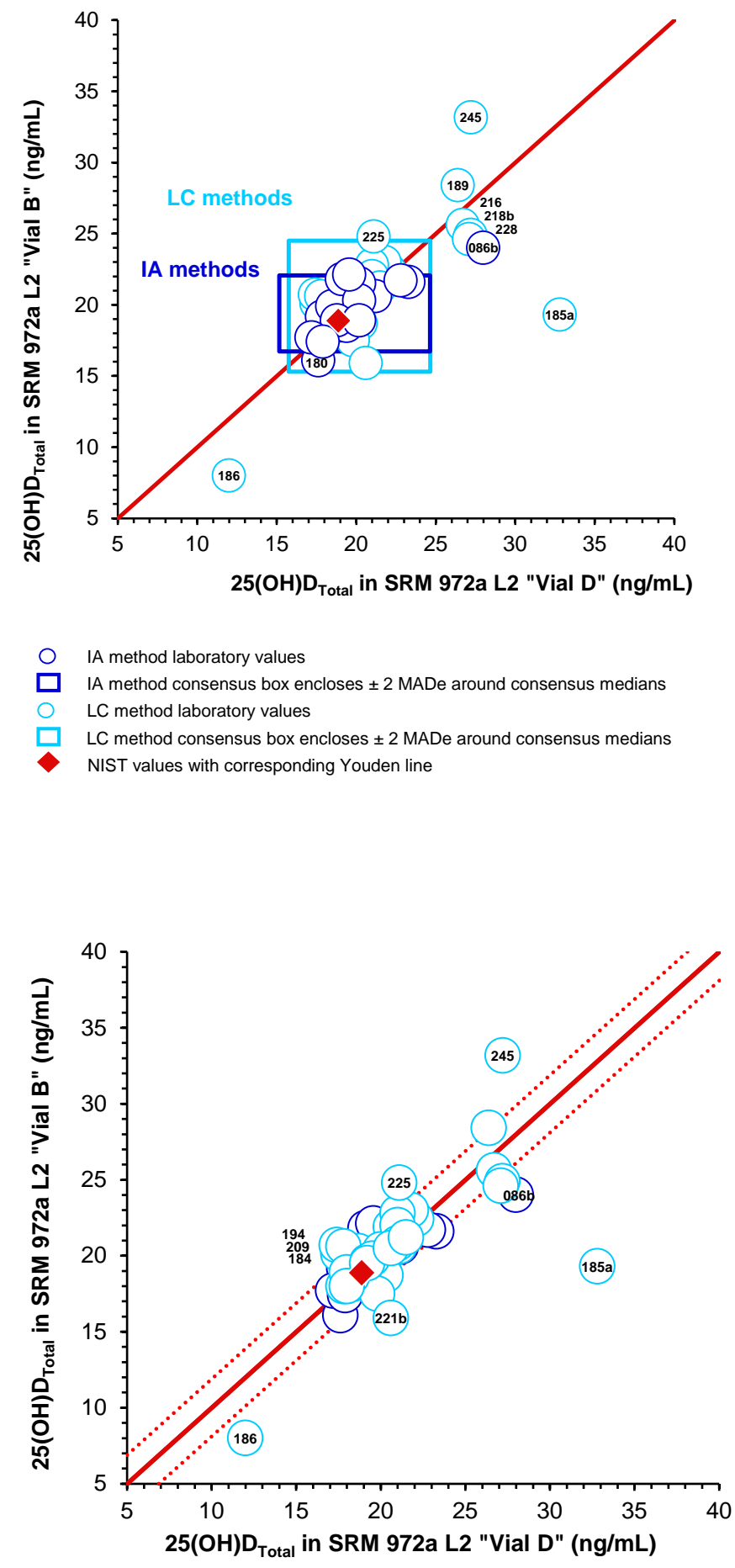

$\begin{array}{ll}\bigcirc & \text { IA method laboratory values } \\ \ldots \ldots \ldots & \text { LC } \text { method laboratory values } \\ \ldots \ldots & \text { NIST value with corresponding } y=x \text { and } \pm 10 \% \text { lines }\end{array}$
Figure 3. Youden comparison plot of the results for 25(OH)D $D_{\text {Total }}$ in SRM 972a L2 "Vial B" and "Vial D" for all methods

Panel A: Data that fall outside the consensus boxes are labeled with their laboratory number.
Panel B: Data for the two replicates that are more than $10 \%$ discrepant are labeled with their laboratory number. 


\section{Correlation of 25(OH)D in SRM 1950, SRM 972a L2, and W012-3 with Clinical Ranges}

The current guidance regarding 25(OH)D concentrations and human health (obtained from the NIH website) is presented in Table 3.

Table 3. Serum 25-Hydroxyvitamin D [25(OH)D] Concentrations and Health [1]

\begin{tabular}{|l|l|l|}
\hline $\mathbf{n g} / \mathbf{m L}$ & $\mathbf{n m o l} / \mathbf{L}$ & Health Status \\
\hline$<12$ & $<30$ & $\begin{array}{l}\text { Associated with vitamin D deficiency, leading to rickets } \\
\text { in infants and children and osteomalacia in adults }\end{array}$ \\
\hline $12-20$ & $30-50$ & $\begin{array}{l}\text { Generally considered inadequate for bone and overall } \\
\text { health in healthy individuals }\end{array}$ \\
\hline$\geq 20$ & $\geq 50$ & $\begin{array}{l}\text { Generally considered adequate for bone and overall } \\
\text { health in healthy individuals }\end{array}$ \\
\hline$>50$ & $>125$ & $\begin{array}{l}\text { Emerging evidence links potentially adverse effects to } \\
\text { such high levels, particularly }>150 \text { nmol/L ( }>60 \mathrm{ng} / \mathrm{mL})\end{array}$ \\
\hline
\end{tabular}

Table from http://ods.od.nih.gov/factsheets/vitamind\#h4

[1] Institute of Medicine, Food and Nutrition Board. Dietary Reference Intakes for Calcium and Vitamin D. Washington, DC: National Academy Press, 2010.

Graphical representations of the single reported values for 25(OH)D $\mathrm{D}_{\text {Total }}$ in SRM 1950 and SRM 968d L1 and the mean values with error bars (representing the lab mean value $\pm 2 \times \mathrm{SD}$ ) for 25(OH)D $\mathrm{D}_{\text {Total }}$ in SRM 972a L2 overlaid with the clinical ranges from Table 3 are presented in Figure 4. Specific results as assessed from Figure 4 are summarized below:

SRM 1950

- All but one of the participant results are in the adequate 25(OH)D concentration range.

- The NIST value $(25.3 \mathrm{ng} / \mathrm{mL} \pm 0.8 \mathrm{ng} / \mathrm{mL})$ is in the adequate $25(\mathrm{OH}) \mathrm{D}$ concentration range.

SRM 972a L2

- The participant results are almost equally split between the inadequate and adequate 25(OH)D concentration ranges.

- The NIST value $(18.9 \mathrm{ng} / \mathrm{mL} \pm 0.4 \mathrm{ng} / \mathrm{mL})$ is in the inadequate $25(\mathrm{OH}) \mathrm{D}$ concentration range.

SRM 968d L1

- The range of participant results for SRM 968d L1 is larger than for the other materials.

- The majority of participant results are in the inadequate 25(OH)D concentration range, but several also reported deficient and adequate concentration values.

- The NIST value $(12.4 \mathrm{ng} / \mathrm{mL} \pm 0.3 \mathrm{ng} / \mathrm{mL})$ is in the inadequate $25(\mathrm{OH}) \mathrm{D}$ concentration range.

The consensus $\mathrm{CV} \%$ of the participant results from all methods was $\approx 10 \%$ for the study materials (Table 2). Large consensus variability has implications regarding the accuracy of 25(OH)D measurements for the diagnosis of vitamin $\mathrm{D}$ status, particularly given the narrow ranges associated with vitamin D deficiency and inadequacy. 
Figure 4. 25(OH) $\mathrm{D}_{\text {Total }}$ levels in SRM 1950, SRM 972a L2, and SRM 968d L1 superimposed over clinically-relevant serum 25-hydroxyvitamin D $\left(25(\mathrm{OH}) \mathrm{D}_{\text {Total }}\right)$ concentration levels as reported by $\mathrm{NIH}$ (Table 3). The grey-shaded bars represent the ranges bound by the NIST values with \pm estimated $U_{95}$ uncertainty. The error bars represent $2 \times$ SD of the duplicate results.
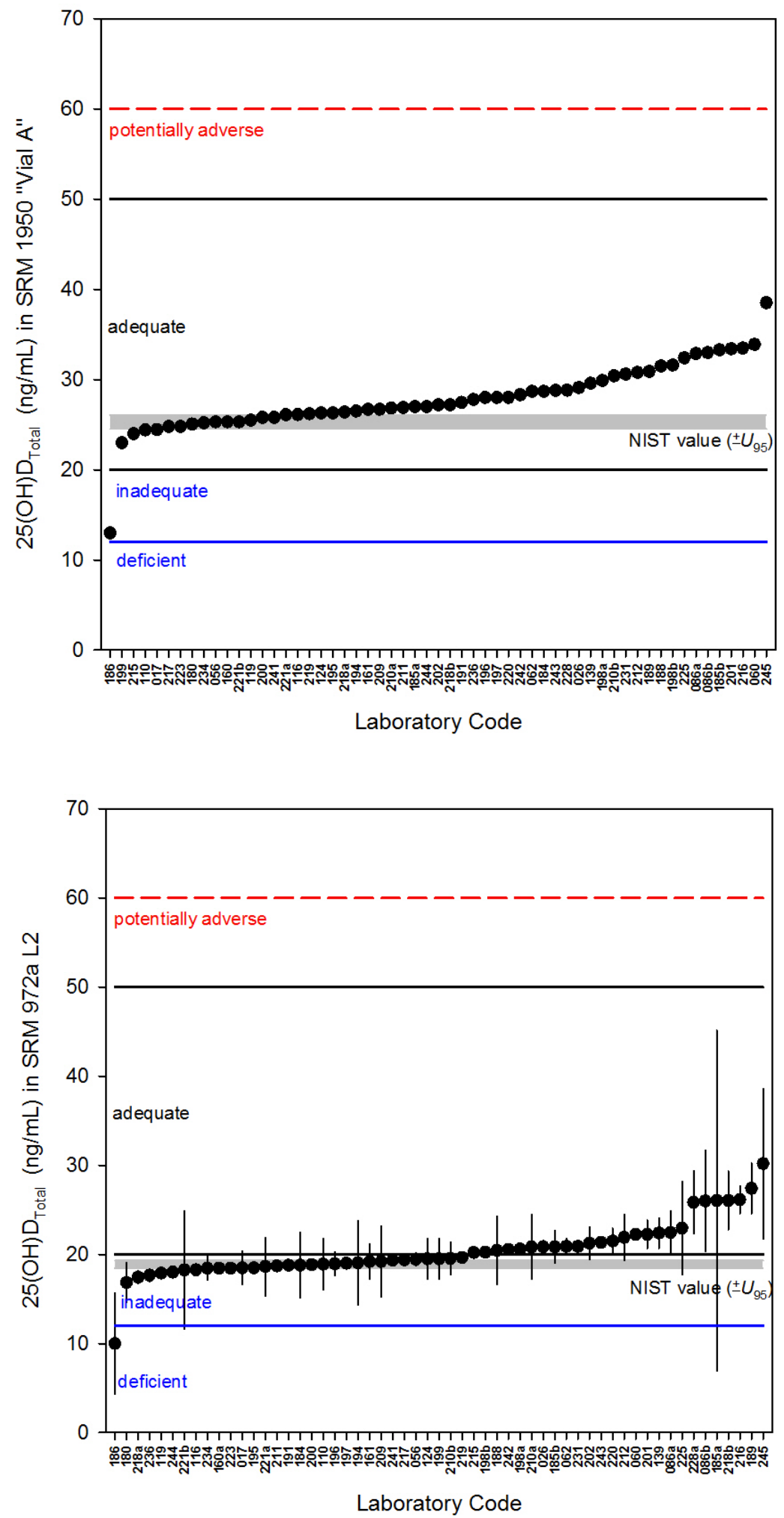
Figure 4 (cont'd) 25(OH)D $D_{\text {Total }}$ levels in SRM 1950, SRM 972a L2, and SRM 968d L1 superimposed over clinically-relevant serum 25 -hydroxyvitamin $\mathrm{D}\left(25(\mathrm{OH}) \mathrm{D}_{\text {Total }}\right)$ concentration levels as reported by NIH (Table 3). The grey-shaded bars represent the ranges bound by the NIST values with \pm estimated $U_{95}$ uncertainty.

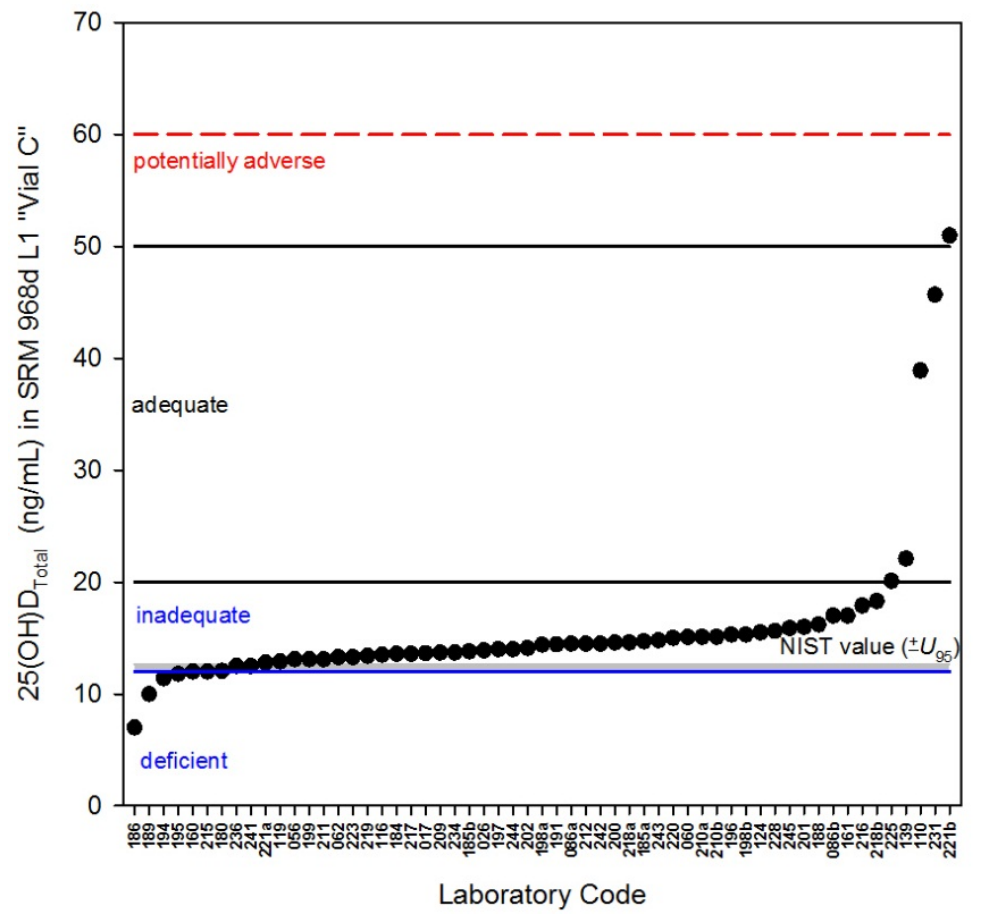


Appendix A-1. Summary of immunoassay methods used by participants.

\begin{tabular}{|c|c|c|c|}
\hline $\begin{array}{l}\text { Laboratory } \\
\text { Number }\end{array}$ & IA Method & Sample Preparation & Detection \\
\hline 17 & CLIA & $\mathrm{n} / \mathrm{r}$ & $\mathrm{n} / \mathrm{r}$ \\
\hline 62 & RIA & $n / r$ & $n / r$ \\
\hline $86 a$ & CLIA & $\mathrm{n} / \mathrm{r}$ & $\mathrm{n} / \mathrm{r}$ \\
\hline $86 b$ & RIA & $\mathrm{n} / \mathrm{r}$ & $\mathrm{n} / \mathrm{r}$ \\
\hline 161 & CLIA & $\begin{array}{l}\text { Sample incubated for } 30 \text { min with anti-25(OH)D antibodies } \\
\text { attached to paramagnetic particles in a buffer that dissociates } \\
25(\mathrm{OH}) \mathrm{D} \text { from binding proteins. Magnetic separation and } \\
\text { washing removes unbound reagents. Trigger reagent used to } \\
\text { initiate the chemiluminescent reaction. }\end{array}$ & $\begin{array}{l}\text { Relative light units (from } \\
\text { luminometer) are compared } \\
\text { to a stored master curve to } \\
\text { determine the concentration } \\
\text { of } 25(\mathrm{OH}) \mathrm{D}\end{array}$ \\
\hline 180 & RIA & Samples prepared per manufacturer's instructions & $1^{125}$ detection \\
\hline $185 b$ & CLIA & $\mathrm{n} / \mathrm{r}$ & $\mathrm{n} / \mathrm{r}$ \\
\hline 188 & EIA & None & $\mathrm{n} / \mathrm{r}$ \\
\hline 191 & RIA & Samples were prepared as per kit protocol & $\begin{array}{l}1^{125} \text { detection using Gamma } \\
\text { counter }\end{array}$ \\
\hline 196 & CLIA & $\begin{array}{l}\text { The human serum samples were analyzed neat; calibration } \\
\text { solutions were diluted 1:4 in a diluent mix and analyzed. }\end{array}$ & $\mathrm{n} / \mathrm{r}$ \\
\hline $198 b$ & EIA & $\mathrm{n} / \mathrm{r}$ & $\mathrm{n} / \mathrm{r}$ \\
\hline 200 & RIA & Sample was extracted & $\mathrm{n} / \mathrm{r}$ \\
\hline 201 & EIA & $\mathrm{n} / \mathrm{r}$ & $\mathrm{n} / \mathrm{r}$ \\
\hline $210 a$ & RIA & Sample was extracted with acetonitrile & $\mathrm{n} / \mathrm{r}$ \\
\hline $210 b$ & CLIA & $\mathrm{n} / \mathrm{r}$ & $\mathrm{n} / \mathrm{r}$ \\
\hline $218 a$ & CLIA & Direct analysis & $\mathrm{n} / \mathrm{r}$ \\
\hline 236 & CLIA & Centrifuged & $n / r$ \\
\hline
\end{tabular}

$\mathrm{n} / \mathrm{r}=$ not reported 
Appendix A-2. Summary of LC-MS ${ }^{\mathrm{n}}$ methods reported by participants.

\begin{tabular}{|c|c|c|c|c|}
\hline $\begin{array}{l}\text { Laboratory } \\
\text { Number }\end{array}$ & $\begin{array}{c}\text { Internal Standard } \\
\text { (IS) }\end{array}$ & Sample Preparation & Chromatographic Conditions & Detection: MRM ions \\
\hline 26 & $\begin{array}{l}25(\mathrm{OH}) \mathrm{D}_{2}-d_{6} \text { and } \\
25(\mathrm{OH}) \mathrm{D}_{3}-d_{6}\end{array}$ & Liquid-liquid extraction method & $\begin{array}{l}\text { C18 column }(50 \times 2.1 \mathrm{~mm}) \text {; isocratic } \\
\text { separation with } 95 \% \text { methanol, } 5 \% \\
\text { water; flow } 0.2 \mathrm{~mL} / \mathrm{min}\end{array}$ & $\begin{array}{l}25(\mathrm{OH}) \mathrm{D}_{2} 413 / 355 \\
25(\mathrm{OH}) \mathrm{D}_{3} 401 / 365\end{array}$ \\
\hline 56 & $\begin{array}{c}25(\mathrm{OH}) \mathrm{D}_{2}-d_{3 ;} \\
25(\mathrm{OH}) \mathrm{D}_{3}-d_{6 ;} ;-\mathrm{epi} \\
25(\mathrm{OH}) \mathrm{D}_{2}-d_{3}\end{array}$ & $\begin{array}{l}\text { Samples were extracted with } \\
\text { hexane, evaporated, then } \\
\text { reconstituted with } 69 \% \text { methanol }\end{array}$ & $\begin{array}{l}\text { PFP column }(100 \times 2.1 \mathrm{~mm} ; 1.9 \\
\mu \mathrm{m}) ; \text { isocratic elution; flow } 0.4 \\
\mathrm{~mL} / \mathrm{min}\end{array}$ & $\begin{array}{l}25(\mathrm{OH}) \mathrm{D}_{3} 383 / 365 \\
25(\mathrm{OH}) \mathrm{D}_{3}-d_{6} 389 / 371 \\
25(\mathrm{OH}) \mathrm{D}_{2} 395 / 377 \\
25(\mathrm{OH}) \mathrm{D}_{2}-d_{3} 398 / 380\end{array}$ \\
\hline 60 & $25(\mathrm{OH}) \mathrm{D}_{3}-d_{6}$ & $\begin{array}{l}\text { Serum proteins were precipitated } \\
\text { with acetonitrile containing the IS, } \\
\text { followed by centrifugation and } \\
\text { injection of the supernatant }\end{array}$ & $\mathrm{n} / \mathrm{r}$ & $\begin{array}{l}25(\mathrm{OH}) \mathrm{D}_{3} 383 / 211 ; \\
25(\mathrm{OH}) \mathrm{D}_{3}-d_{6} 389 / 211 ; \\
25(\mathrm{OH}) \mathrm{D}_{2} 395 / 269\end{array}$ \\
\hline 116 & $25(\mathrm{OH}) \mathrm{D}_{3}-d_{6}$ & $\begin{array}{l}\text { Serum proteins were precipitated, } \\
\text { followed by centrifugation and } \\
\text { injection of the supernatant }\end{array}$ & 2-dimensional LC-MS/MS & $\begin{array}{l}25(\mathrm{OH}) \mathrm{D}_{3} 383 / 211 ; \\
25(\mathrm{OH}) \mathrm{D}_{3}-d_{6} 389 / 211 \\
25(\mathrm{OH}) \mathrm{D}_{2} 395 / 269\end{array}$ \\
\hline 119 & $25(\mathrm{OH}) \mathrm{D}_{3}-d_{6}$ & $\begin{array}{l}\text { IS was added and serum }(150 \mu \mathrm{L}) \\
\text { proteins were precipitiated with } \\
\text { methanol }(150 \mu \mathrm{L}) \text {, followed by } \\
\text { hexane extraction }(1.5 \mathrm{~mL}) \text {, } \\
\text { evaporation, and reconstitution } \\
\text { with methanol }(150 \mu \mathrm{L})\end{array}$ & $\begin{array}{l}\text { C18 column }(150 \times 3.0 \mathrm{~mm}, 2.7 \\
\mu \mathrm{m}) \text {; gradient with methanol and } \\
\text { water }(0.1 \% \text { formic acid); flow } 0.65 \\
\mathrm{mL} / \mathrm{min}\end{array}$ & $\begin{array}{l}\text { Orbitrap MS } \\
25(\mathrm{OH}) \mathrm{D}_{3} 401.33824 \\
25(\mathrm{OH}) \mathrm{D}_{3}-d_{6} 407.37907 \\
25(\mathrm{OH}) \mathrm{D}_{2} 413.33929\end{array}$ \\
\hline 124 & $\begin{array}{l}25(\mathrm{OH}) \mathrm{D}_{2}-d_{6} \text { and } \\
25(\mathrm{OH}) \mathrm{D}_{3}-d_{6}\end{array}$ & Solid-phase extraction & $\begin{array}{l}\text { Phenyl column }(50 \times 2.1 \mathrm{~mm} \text {; } \\
1.7 \mu \mathrm{m}) \text {, gradient with } \\
\text { methanol/water (both with } \\
\text { ammonium acetate and formic acid) }\end{array}$ & $\mathrm{n} / \mathrm{r}$ \\
\hline 160 & $\begin{array}{c}25(\mathrm{OH}) \mathrm{D}_{2}-d_{6} \text { and } \\
25(\mathrm{OH}) \mathrm{D}_{3}-d_{6}\end{array}$ & $\begin{array}{l}\text { IS added to sample, followed by } \\
\text { centrifugation, evaporation, } \\
\text { reconstitution, mixing, and } \\
\text { centrifugation (all using filter } \\
\text { plate) }\end{array}$ & $\begin{array}{l}\text { C18 column }(50 \times 2.1 \mathrm{~mm}) \text {; gradient } \\
\text { with methanol/water; flow } 0.7 \\
\mathrm{~mL} / \mathrm{min}\end{array}$ & MS/MS at $m / z 413.3 / 337.3$ \\
\hline 184 & $25(\mathrm{OH}) \mathrm{D}_{3}-d_{6}$ & $\begin{array}{l}\text { Serum }(200 \mu \mathrm{L}) \text { treated with } \\
\text { acetonitrile containing IS ( } 700 \\
\mu \mathrm{L}) \text {; mixed, centrifuged, and } \\
\text { filtered }\end{array}$ & $\begin{array}{l}\text { C18 column }(100 \times 2.1 \mathrm{~mm} ; 5 \mu \mathrm{m}) \\
\text { Linear gradient from } 40 \% \mathrm{~A}(0.1 \% \\
\text { formic acid in water) and } 60 \% \mathrm{~B} \\
\text { ( } 0.1 \% \text { formic acid } / 5 \mathrm{mM} \text { ammonium } \\
\text { acetate in methanol) } 98 \% \mathrm{~B} \text { in } 2 \mathrm{~min}\end{array}$ & $\begin{array}{l}25(\mathrm{OH}) \mathrm{D}_{3} 383 / 257 \\
25(\mathrm{OH}) \mathrm{D}_{3}-d_{6} 389 / 263 \\
25(\mathrm{OH}) \mathrm{D}_{2} 395 / 209\end{array}$ \\
\hline $185 a$ & $\begin{array}{c}25(\mathrm{OH}) \mathrm{D}_{2}-d_{6} \text { and } \\
25(\mathrm{OH}) \mathrm{D}_{3}-d_{6}\end{array}$ & $\begin{array}{l}\text { Liquid-liquid extraction; } 40 \mu \mathrm{L} \\
\text { sample }\end{array}$ & $\begin{array}{l}\text { C18 column; methanol/water } \\
\text { gradient }\end{array}$ & MRM \\
\hline 186 & $25(\mathrm{OH}) \mathrm{D}_{3}-d_{6}$ & $\begin{array}{l}\text { Sample was deproteinized in } \\
\text { acetone, extracted with } 3 \text { volumes } \\
\text { of hexanes, evaporated, and } \\
\text { reconstituted in methanol/water }\end{array}$ & C18 column ( 50 x $2.1 \mathrm{~mm} ; 1.7 \mu \mathrm{m})$ & $\begin{array}{l}25(\mathrm{OH}) \mathrm{D}_{3} 401 / 383 \text { (quant), } \\
401 / 159 \text { (qual); } 25(\mathrm{OH}) \mathrm{D}_{3}-d_{6} \\
407 / 159\end{array}$ \\
\hline 194 & $25(\mathrm{OH}) \mathrm{D}_{3}-d_{6}$ & $\begin{array}{l}\text { Proteins precipitated with } \\
\text { acetonitrile, top layer removed, } \\
\text { evaporated, and reconstituted } \\
\text { with methanol }\end{array}$ & C8 column $(50 \times 2 \mathrm{~mm})$ & $\begin{array}{l}25(\mathrm{OH}) \mathrm{D}_{2} 395.3 / 119.0 \\
25(\mathrm{OH}) \mathrm{D}_{3} 383.4 / 211.3\end{array}$ \\
\hline 195 & $\begin{array}{c}25(\mathrm{OH}) \mathrm{D}_{2}-d_{3} \text { and } \\
25(\mathrm{OH}) \mathrm{D}_{3}-d_{6}\end{array}$ & $\begin{array}{l}\text { Samples extracted then } \\
\text { derivatized }\end{array}$ & $\begin{array}{l}\text { LC column }(30 \times 2.1 \mathrm{~mm}) \text {; gradient } \\
\text { with methanol/water }\end{array}$ & $\mathrm{n} / \mathrm{r}$ \\
\hline 197 & $25(\mathrm{OH}) \mathrm{D}_{3}-d_{6}$ & $\begin{array}{l}\text { Precipitating agent added }(200 \mu \mathrm{L} \\
\text { with } 20 \text { ng IS) to each serum }(200 \\
\mu \mathrm{L}), \text { calibrator and control sample } \\
\text { followed by mixing, centrifugation, } \\
\text { and analysis }\end{array}$ & $\begin{array}{l}\text { C18 column }(50 \times 4.6 \mathrm{~mm} ; 5 \mu \mathrm{m}) \\
\text { flow } 1.0 \mathrm{~mL} / \mathrm{min} \text {; column temp } 45^{\circ} \mathrm{C} ; \\
\text { gradient with water and methanol }\end{array}$ & $n / r$ \\
\hline
\end{tabular}




\begin{tabular}{|c|c|c|c|c|}
\hline $198 \mathrm{a}$ & $25(\mathrm{OH}) \mathrm{D}_{3}-d_{6}$ & $\begin{array}{l}\text { Proteins precipitated with } \\
\text { methanol, followed by hexane } \\
\text { extraction, centrifugation, } \\
\text { evaporation under } \mathrm{N}_{2} \text {, and } \\
\text { reconstitution in methanol }(0.1 \% \\
\text { formic acid) }\end{array}$ & $\begin{array}{l}\text { C18 column }(50 \times 2.1 \mathrm{~mm} ; 3.5 \mu \mathrm{m}) \text {; } \\
\text { isocratic elution with } 85 \% \text { methanol } \\
(0.1 \% \text { formic acid }) \text {; flow } 0.5 \mathrm{~mL} / \mathrm{min}\end{array}$ & $\begin{array}{l}25(\mathrm{OH}) \mathrm{D}_{3} 401 / 383,401 / 365 ; \\
25(\mathrm{OH}) \mathrm{D}_{2} 413 / 395,413 / 355 \\
25(\mathrm{OH}) \mathrm{D}_{3}-d_{6} 407 / 389 \\
407 / 371\end{array}$ \\
\hline 199 & $\mathrm{n} / \mathrm{r}$ & $\mathrm{n} / \mathrm{r}$ & $\mathrm{n} / \mathrm{r}$ & $n / r$ \\
\hline 202 & $\begin{array}{l}d_{6} \text {-labeled } \\
\text { compound }\end{array}$ & Sample was extracted & $\begin{array}{l}\text { C18 column }(50 \times 2.1 \mathrm{~mm}) \text {; gradient } \\
\text { with } 10 \% \text { acetonitrile }(0.1 \% \text { formic } \\
\text { acid), } 90 \% \text { methanol; flow } 0.3 \\
\mathrm{~mL} / \mathrm{min}\end{array}$ & $n / r$ \\
\hline 209 & $25(\mathrm{OH}) \mathrm{D}_{3}-d_{6}$ & $\begin{array}{l}\text { Proteins were precipitated with } \\
\mathrm{ZnSO}_{4} \text { in methanol }\end{array}$ & $\begin{array}{l}\text { C8 column }(50 \times 2 \mathrm{~mm} ; 5 \mu \mathrm{m}) \text {; } \\
\text { gradient with water/methanol; flow } \\
0.7 \mathrm{~mL} / \mathrm{min}\end{array}$ & $\begin{array}{l}25(\mathrm{OH}) \mathrm{D}_{3} 383 / 229,383 / 211 ; \\
25(\mathrm{OH}) \mathrm{D}_{3}-d_{6} 389 / 211 ; \\
25(\mathrm{OH}) \mathrm{D}_{2} 395 / 269,395 / 119\end{array}$ \\
\hline 211 & $25(\mathrm{OH}) \mathrm{D}_{3}-d_{6}$ & $\begin{array}{l}\text { Extraction with acetonitrile } \\
\text { containing IS followed by } \\
\text { centrifugation }\end{array}$ & Column $(33 \times 4.6 \mathrm{~mm} ; 3 \mu \mathrm{m})$ & $\begin{array}{l}25(\mathrm{OH}) \mathrm{D}_{3} 383 / 365 \text { (quant), } \\
383 / 357 \text { (qual); } 25(\mathrm{OH}) \mathrm{D}_{2} \\
395 / 377 \text { (quant), } 395 / 209 \\
\text { (qual) }\end{array}$ \\
\hline 212 & $25(\mathrm{OH}) \mathrm{D}_{3}-d_{6}$ & $\begin{array}{l}\text { Serum }(100 \mu \mathrm{L}) \text { precipitated with } \\
5: 95 \text { methanol:acetonitrile }(350 \\
\mu \mathrm{L}) \text { containing the deuterated IS }\end{array}$ & $\begin{array}{l}\text { C8 column }(50 \times 2 \mathrm{~mm} ; 3 \mu \mathrm{m}) \\
\text { gradient starting with } 60 \% \\
\text { acetonitrile }(0.1 \% \text { formic acid), } 40 \% \\
\text { water }(0.1 \% \text { formic acid })\end{array}$ & $\begin{array}{l}25(\mathrm{OH}) \mathrm{D}_{3} 383 / 229,383 / 211 ; \\
25(\mathrm{OH}) \mathrm{D}_{3}-d_{6} 389 / 211 ; \\
25(\mathrm{OH}) \mathrm{D}_{2} 395 / 269,395 / 119\end{array}$ \\
\hline 215 & $25(\mathrm{OH}) \mathrm{D}_{3}-d_{6}$ & $\begin{array}{l}\text { Protein precipitation with } \\
\text { methanol/isopropanol and } \mathrm{ZnSO}_{4} ; \\
\text { supernatant extracted using solid } \\
\text { phase extraction }\end{array}$ & $\begin{array}{l}\text { C18 column }(50 \times 2.1 \mathrm{~mm} ; 2.6 \mu \mathrm{m}) \\
\text { column; gradient with water }(0.1 \% \\
\text { formic acid, } 5 \mathrm{mmol} / \mathrm{L} \text { ammonium } \\
\text { formate) and methanol }(0.05 \% \\
\text { formic acid) }\end{array}$ & $\begin{array}{l}25(\mathrm{OH}) \mathrm{D}_{3} 401 / 383 \\
25(\mathrm{OH}) \mathrm{D}_{2} 413 / 395 \\
25(\mathrm{OH}) \mathrm{D}_{3}-d_{6} 407 / 389\end{array}$ \\
\hline 216 & $\begin{array}{c}25(\mathrm{OH}) \mathrm{D}_{2}-d_{3} \text { and } \\
25(\mathrm{OH}) \mathrm{D}_{3}-d_{6}\end{array}$ & $\begin{array}{l}\text { Samples extracted using liquid- } \\
\text { liquid extraction then labeled with } \\
\text { a derivatization reagent }\end{array}$ & $\begin{array}{l}\text { C18 column }(200 \times 2.1 \mathrm{~mm}) ; \\
\text { gradient from } 25 \% \text { water }(0.05 \% \\
\text { formic acid) to } 50 \% \text { acetonitrile } \\
(0.05 \% \text { formic acid); flow } 0.2 \\
\mathrm{mL} / \mathrm{min}\end{array}$ & $\mathrm{n} / \mathrm{r}$ \\
\hline 217 & $25(\mathrm{OH}) \mathrm{D}_{3}-d_{6}$ & $\begin{array}{l}\text { Protein precipitation with } \mathrm{ZnSO}_{4} \text { in } \\
\text { methanol followed by solid phase } \\
\text { extraction }\end{array}$ & $\begin{array}{l}\text { C8 column }(50 \times 2.1 \mathrm{~mm} ; 1.7 \mu \mathrm{m}) \text {; } \\
\text { gradient of } 70 \% \text { to } 98 \% \text { methanol } \\
\text { (with } 0.1 \% \text { formic acid); flow } 0.4 \\
\mathrm{~mL} / \mathrm{min}\end{array}$ & $\begin{array}{l}25(\mathrm{OH}) \mathrm{D}_{3} 401 / 159 \text { (quant), } \\
401 / 383 \text { (qual); } 25(\mathrm{OH}) \mathrm{D}_{2} \\
413 / 88 \text { (quant), } 413 / 395 \\
\text { (qual) }\end{array}$ \\
\hline $218 b$ & $\begin{array}{c}25(\mathrm{OH}) \mathrm{D}_{2}-d_{3} \text { and } \\
25(\mathrm{OH}) \mathrm{D}_{3}-d_{3}\end{array}$ & $\begin{array}{l}\text { Sample was extracted, filtered, } \\
\text { centrifuged, etc. }\end{array}$ & $\begin{array}{l}\text { Phenyl column }(50 \times 2.1 \mathrm{~mm} ; 1.7 \\
\mu \mathrm{m}) ; \text { flow } 0.45 \mathrm{~mL} / \mathrm{min}\end{array}$ & $\begin{array}{l}25(\mathrm{OH}) \mathrm{D}_{3} 401 \\
25(\mathrm{OH}) \mathrm{D}_{2} 413\end{array}$ \\
\hline 219 & $25(\mathrm{OH}) \mathrm{D}_{3}-d_{6}$ & $\begin{array}{l}\text { Samples were protein crashed in } \\
\text { conjunction with internal standard } \\
\text { addition, vortexed, centrifuged }\end{array}$ & Automated 2-dimensional system & $\begin{array}{l}25(\mathrm{OH}) \mathrm{D}_{3} 401 / 365 ; \\
25(\mathrm{OH}) \mathrm{D}_{2} 413 / 355 \\
25(\mathrm{OH}) \mathrm{D}_{3}-d_{6} 407 / 371\end{array}$ \\
\hline 220 & $\begin{array}{c}25(\mathrm{OH}) \mathrm{D}_{2}-d_{3} \text { and } \\
25(\mathrm{OH}) \mathrm{D}_{3}-d_{6}\end{array}$ & $\begin{array}{l}\text { Protein crash with } 90 \% \text { methanol, } \\
10 \% \mathrm{ZnSO}_{4} \text { and then acetonitrile } \\
\text { ( } 1 \% \text { formic acid); sample filtered } \\
\text { then phospholipids removed with } \\
\text { solid phase extraction }\end{array}$ & $\begin{array}{l}\text { C18 column }(20 \times 2.1 \mathrm{~mm}, 2.7 \mu \mathrm{m}) \\
\text { gradient with water and acetonitrile; } \\
\text { flow } 1 \mathrm{~mL} / \mathrm{min} \text {; column } 40^{\circ} \mathrm{C}\end{array}$ & $\begin{array}{l}25(\mathrm{OH}) \mathrm{D}_{3} 383 / 211 \text { (quant), } \\
383 / 229 \text { (qual); } 25(\mathrm{OH}) \mathrm{D}_{2} \\
395 / 119 \text { (quant), 395/269 } \\
\text { (qual); } 25(\mathrm{OH}) \mathrm{D}_{3}-d_{6} 389 / 211 ; \\
25(\mathrm{OH}) \mathrm{D}_{2}-d_{3} 398 / 272\end{array}$ \\
\hline $221 a$ & $25(\mathrm{OH}) \mathrm{D}_{3}-d_{6}$ & $\begin{array}{l}\text { Protein crash with } 1 \% \text { methanol in } \\
\text { acetonitrile containing IS }\end{array}$ & $\begin{array}{l}\mathrm{CN} \text { column }(50 \times 3.0 \mathrm{~mm} ; 1.8 \mu \mathrm{m}) \\
\text { methanol/water gradient at } 50^{\circ} \mathrm{C}\end{array}$ & $\begin{array}{l}25(\mathrm{OH}) \mathrm{D}_{3} 383 / 211 \\
25(\mathrm{OH}) \mathrm{D}_{3}-d_{6} 389 / 211 \\
25(\mathrm{OH}) \mathrm{D}_{2} 395 / 209\end{array}$ \\
\hline 223 & $\begin{array}{c}25(\mathrm{OH}) \mathrm{D}_{2}-d_{3} \text { and } \\
25(\mathrm{OH}) \mathrm{D}_{3}-d_{6}\end{array}$ & $\begin{array}{l}\text { Protein precipitation with } \\
\text { methanol followed by liquid-liquid } \\
\text { extraction with cyclohexane:ethyl } \\
\text { acetate }(9: 1) \text {; supernatant } \\
\text { evaporated then derivatized with } 4 \\
\text { phenyl-1,2,4-triazoline-3,5-dione } \\
\text { in acetonitrile }\end{array}$ & $\begin{array}{l}\text { C18 column }(100 \times 2.1 \mathrm{~mm} ; 1.7 \\
\mu \mathrm{m}) ; \text { gradient with water, } \\
\text { acetonitrile, } 0.01 \% \text { formic acid }\end{array}$ & $\begin{array}{l}25(\mathrm{OH}) \mathrm{D}_{3} 558 / 298 \\
25(\mathrm{OH}) \mathrm{D}_{3}-d_{6} 564 / 298 \\
25(\mathrm{OH}) \mathrm{D}_{2} 570 / 298 \\
25(\mathrm{OH}) \mathrm{D}_{2}-d_{3} 573 / 301\end{array}$ \\
\hline
\end{tabular}




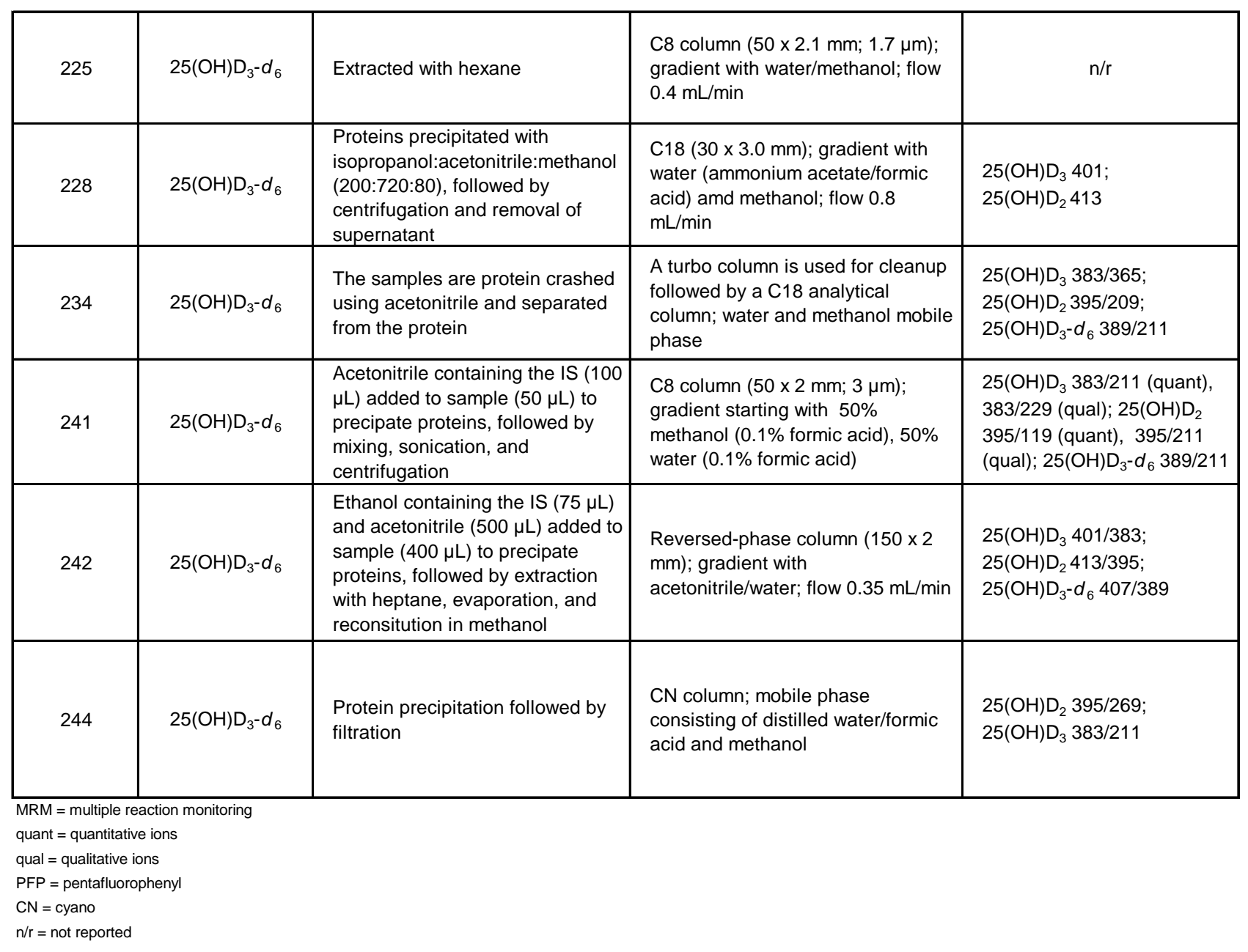


Appendix A-3. Summary of LC-UV methods used by participants.

\begin{tabular}{|c|c|c|c|c|}
\hline $\begin{array}{l}\text { Laboratory } \\
\text { Number }\end{array}$ & $\begin{array}{c}\text { Internal Standard } \\
\text { (IS) }\end{array}$ & Sample Preparation & Chromatographic Conditions & Wavelength \\
\hline 110 & $n / r$ & $\begin{array}{l}\text { Samples were extracted twice with } \\
\text { hexane/methylene chloride }(5: 1) \text {, } \\
\text { evaporated and reconstituted }\end{array}$ & $\begin{array}{l}\text { Ultra-fast LC; gradient with } \\
\text { acetonitrile:methanol }(85: 15) \text { and } \\
\text { isopropanol }(100 \%)\end{array}$ & $268 \mathrm{~nm}$ \\
\hline 139 & Proprietary & $\begin{array}{l}\text { The sample was extracted, } \\
\text { centrifuged and injected }\end{array}$ & $\begin{array}{l}\text { Reversed-phase column, isocratic } \\
\text { separation with proprietary mobile } \\
\text { phase; flow } 1 \mathrm{~mL} / \mathrm{min}\end{array}$ & $264 \mathrm{~nm}$ \\
\hline 189 & $\begin{array}{l}\text { Added before } \\
\text { extraction }\end{array}$ & $\begin{array}{l}\text { Proteins were disrupted and } \\
\text { precipitated; analytes were } \\
\text { extracted using solid-phase } \\
\text { extraction }\end{array}$ & $\begin{array}{l}\text { LC column }(150 \times 4.6 \mathrm{~mm}) \text {; isocratic } \\
\text { separation with commercial mobile } \\
\text { phase; flow } \\
0.7 \mathrm{~mL} / \mathrm{min}\end{array}$ & $265 \mathrm{~nm}$ \\
\hline $221 b$ & Laurophenone & $\begin{array}{l}\text { Protein crash with acetonitrile } \\
\text { (contaning IS), followed by } \\
\text { extraction on C-18 sorbent, } \\
\text { elution with methanol/acetonitrile, } \\
\text { evaporation, and reconstitution } \\
\text { with acetonitrile }\end{array}$ & $\begin{array}{l}\mathrm{CN} \text { column }(150 \times 4.6 \mathrm{~mm} ; 3.5 \mu \mathrm{m}) \\
\text { methanol/water/formic acid mobile } \\
\text { phase; } 47^{\circ} \mathrm{C}\end{array}$ & $275 \mathrm{~nm}$ \\
\hline 231 & 1-alpha $(\mathrm{OH}) \mathrm{D}_{3}$ & $\begin{array}{l}\text { Samples were extracted with } \\
\text { hexane/dichloromethane, } \\
\text { evaporated and reconstituted with } \\
\text { mobile phase (phosphate } \\
\text { buffer/acetonitrile) }\end{array}$ & $\begin{array}{l}\text { Reversed-phase column }(250 \times 4.5 \\
\mathrm{mm} ; 5 \mu \mathrm{m}) \text {, isocratic separation with } \\
14 \% \text { phosphate buffer, } 86 \% \\
\text { acetonitrile; flow } 1.2 \mathrm{~mL} / \mathrm{min}\end{array}$ & $265 \mathrm{~nm}$ \\
\hline 243 & Laurophenone & $\begin{array}{l}\text { Reagent } 1 \text { containing the } \\
\text { ethanolic IS }(400 \mu \mathrm{L}) \text { added to } \\
\text { sample }(400 \mu \mathrm{L}) \text {, followed by } \\
\text { vortexing the precipitation reagent } \\
(500 \mu \mathrm{L}) \text { and sampling of the } \\
\text { supernatant }\end{array}$ & $\begin{array}{l}\text { Reversed-phase column ( } 150 \times 3 \\
\mathrm{~mm}) \text {; isocratic separation with } 65 \% \\
\text { acetonitrile, } 35 \% \text { water; flow } 1 \\
\mathrm{~mL} / \mathrm{min}\end{array}$ & $264 \mathrm{~nm}$ \\
\hline 245 & Proprietary & $\begin{array}{l}\text { Precipant added to sample, } \\
\text { followed by addition of IS, mixing, } \\
\text { and centrifugation. }\end{array}$ & Flow $1 \mathrm{~mL} / \mathrm{min}$ & $264 \mathrm{~nm}$ \\
\hline
\end{tabular}

$\mathrm{n} / \mathrm{r}=$ not reported

$\mathrm{CN}=$ cyano 
Appendix B. Raw participant data and NIST results for 25(OH) $\mathrm{D}_{2}, 25(\mathrm{OH}) \mathrm{D}_{3}$ and $25(\mathrm{OH}) \mathrm{D}_{\text {Total }}$ in SRM 1950, SRM 972a L2, SRM 968d L1, and the control solutions, SRM 2972.

\begin{tabular}{|c|c|c|c|c|c|c|c|c|c|c|c|c|c|c|c|}
\hline & \multicolumn{4}{|c|}{$25(\mathrm{OH}) \mathrm{D}_{2}(\mathrm{ng} / \mathrm{mL})$} & \multicolumn{4}{|c|}{$25(\mathrm{OH}) \mathrm{D}_{3}(\mathrm{ng} / \mathrm{mL})$} & \multicolumn{4}{|c|}{$25(\mathrm{OH}) \mathrm{D}_{\text {Total }}(\mathrm{ng} / \mathrm{mL})$} & \multirow{2}{*}{\multicolumn{2}{|c|}{$\frac{25(\mathrm{OH}) \mathrm{D}_{2} / \mathrm{D}_{3}(\mathrm{ng} / \mathrm{mL})}{\mathrm{SRM} 2972}$}} \\
\hline & & \multirow{2}{*}{$\frac{\text { SRM } 1950}{\text { Vial A }}$} & \multirow{2}{*}{\begin{tabular}{|l} 
SRM 972a L2 \\
Vial B
\end{tabular}} & \multirow{2}{*}{\begin{tabular}{|c|} 
SRM 968d L1 \\
Vial C \\
\end{tabular}} & \multirow{2}{*}{\begin{tabular}{|c|} 
SRM 972a L2 \\
Vial D
\end{tabular}} & \multirow{2}{*}{$\frac{\text { SRM } 1950}{\text { Vial A }}$} & \multirow{2}{*}{\begin{tabular}{|c|} 
SRM 972a L2 \\
Vial B \\
\end{tabular}} & \multirow{2}{*}{\begin{tabular}{|c|} 
SRM 968d L1 \\
Vial C \\
\end{tabular}} & SRM 972a L2 & SRM 1950 & \begin{tabular}{|l|} 
SRM 972a L2 \\
\end{tabular} & SRM 968d L1 & SRM 972a L2 & & \\
\hline Lab & Method & & & & & & & & Vial D & Vial A & \begin{tabular}{|l|} 
Vial B \\
\end{tabular} & Vial C & Vial D & $25(\mathrm{OH}) \mathrm{D}_{2}$ & $25(\mathrm{OH}) \mathrm{D}_{3}$ \\
\hline $\begin{array}{ll}017 \\
\end{array}$ & CLIA & $\mathrm{n} / \mathrm{a}$ & \begin{tabular}{|l|} 
n/a \\
\end{tabular} & \begin{tabular}{|l|} 
n/a \\
\end{tabular} & \begin{tabular}{|l|} 
n/a \\
\end{tabular} & $\mathrm{n} / \mathrm{a}$ & $\mathrm{n} / \mathrm{a}$ & $\mathrm{n} / \mathrm{a}$ & $n / a$ & 24.5 & 19.2 & 13.7 & 17.9 & $\mathrm{n} / \mathrm{r}$ & $\mathrm{n} / \mathrm{r}$ \\
\hline 026 & LC-MS/MS & $<1.0$ & 1.0 & $<1.0$ & $<1.0$ & 29.1 & 19.6 & 13.9 & 21.1 & 29.1 & 20.6 & 13.9 & 21.1 & $n / r$ & $n / r$ \\
\hline 056 & LC-MS/MS & 0.5 & 0.7 & $n / d$ & 0.9 & 24.9 & 18.5 & 13.1 & 18.8 & 25.3 & 19.2 & 13.1 & 19.7 & 230.6 & 342.4 \\
\hline 060 & LC-MS/MS & $<2$ & $<2$ & $<2$ & $<2$ & 33.9 & 22.4 & 15.1 & 22.1 & 33.9 & 22.4 & 15.1 & 22.1 & $\mathrm{n} / \mathrm{r}$ & 372.0 \\
\hline 062 & & $\mathrm{n} / \mathrm{a}$ & $\mathrm{n} / \mathrm{a}$ & $\mathrm{n} / \mathrm{a}$ & $n / a$ & $n / a$ & $\mathrm{n} / \mathrm{a}$ & n/a & $\mathrm{n} / \mathrm{a}$ & 28.7 & 20.6 & 13.3 & 21.2 & $\mathrm{n} / \mathrm{r}$ & 323.1 \\
\hline 086a & CLIA & $\mathrm{n} / \mathrm{a}$ & $\mathrm{n} / \mathrm{a}$ & $\mathrm{n} / \mathrm{a}$ & $n / a$ & $\mathrm{n} / \mathrm{a}$ & n/a & $n / a$ & $n / a$ & 32.9 & 21.6 & 14.5 & 23.3 & $n / r$ & $\mathrm{n} / \mathrm{r}$ \\
\hline 086b & RIA & $\mathrm{n} / \mathrm{a}$ & n/a & $n / a$ & n/a & $n / a$ & n/a & n/a & n/a & 33.0 & 24.0 & 17.0 & 28.0 & $n / r$ & $\mathrm{n} / \mathrm{r}$ \\
\hline 110 & LC-UV & $<4$ & $<4$ & $<4$ & $<4$ & 22.2 & 18.1 & 34.7 & 16.1 & 24.4 & 19.9 & 38.9 & 17.9 & 237.1 & 334.1 \\
\hline 116 & LC-MS/MS & $<3.3$ & $<3.3$ & $<3.3$ & $<3.3$ & 26.1 & 18.2 & 13.5 & 18.4 & 26.1 & 18.2 & 13.5 & 18.4 & 245.1 & 334.6 \\
\hline 119 & LC-MS & $n / d$ & $n / d$ & $n / d$ & $\mathrm{n} / \mathrm{d}$ & 25.5 & 18.0 & 12.9 & 17.8 & 25.5 & 18.0 & 12.9 & 17.8 & 182.4 & 343.4 \\
\hline 124 & LC-MS/MS & $<4.0$ & $<4.0$ & $<4.0$ & $<4.0$ & 26.3 & 18.7 & 15.5 & 20.3 & 26.3 & 18.7 & 15.5 & 20.3 & 47.0 & 123.0 \\
\hline 139 & LC-UV & $\mathrm{n} / \mathrm{a}$ & $\mathrm{n} / \mathrm{a}$ & $\mathrm{n} / \mathrm{a}$ & $\mathrm{n} / \mathrm{a}$ & 29.6 & 23.0 & 22.1 & 21.8 & 29.6 & 23.0 & 22.1 & 21.8 & 239.7 & 328.5 \\
\hline $160 a$ & LC-MS/MS & $<1.0$ & $<1.0$ & $<1.0$ & $<1.0$ & 25.3 & 18.6 & 12.0 & 18.3 & 25.3 & 18.6 & 12.0 & 18.3 & 170.0 & 281.0 \\
\hline 161 & CLIA & $n / a$ & $\mathrm{n} / \mathrm{a}$ & $n / a$ & $n / a$ & $\mathrm{n} / \mathrm{a}$ & $\mathrm{n} / \mathrm{a}$ & n/a & n/a & 26.7 & 19.9 & 17.0 & 18.5 & $n / \mathrm{r}$ & $n / \mathrm{r}$ \\
\hline 180 & RIA & n/a & n/a & n/a & n/a & n/a & n/a & $\mathrm{n} / \mathrm{a}$ & n/a & 25.1 & 16.1 & 12.1 & 17.6 & $n / r$ & $\mathrm{n} / \mathrm{r}$ \\
\hline 184 & LC-MS/MS & $<1.0$ & $<1.0$ & $<1.0$ & $<1.0$ & 28.7 & 20.1 & 13.6 & 17.5 & 28.7 & 20.1 & 13.6 & 17.5 & 240.5 & 336.5 \\
\hline $185 a$ & LC-MS/MS & $\mathrm{n} / \mathrm{d}$ & $\mathrm{n} / \mathrm{d}$ & $\mathrm{n} / \mathrm{d}$ & $\mathrm{n} / \mathrm{d}$ & 27.0 & 19.3 & 14.7 & 32.8 & 27.0 & 19.3 & 14.7 & 32.8 & 238.6 & 334.8 \\
\hline $185 b$ & CLIA & $n / a$ & $\mathrm{n} / \mathrm{a}$ & $\mathrm{n} / \mathrm{a}$ & $\mathrm{n} / \mathrm{a}$ & $\mathrm{n} / \mathrm{a}$ & $n / a$ & n/a & n/a & 33.3 & 21.5 & 13.8 & 20.2 & $\mathrm{n} / \mathrm{r}$ & $\mathrm{n} / \mathrm{r}$ \\
\hline 186 & LC-MS/MS & $\mathrm{n} / \mathrm{d}$ & $\mathrm{n} / \mathrm{d}$ & $\mathrm{n} / \mathrm{d}$ & $\mathrm{n} / \mathrm{d}$ & 13.0 & 8.0 & 7.0 & 12.0 & 13.0 & 8.0 & 7.0 & 12.0 & 238.0 & 335.0 \\
\hline 188 & CLIA & n/a & $\mathrm{n} / \mathrm{a}$ & $\mathrm{n} / \mathrm{a}$ & $\mathrm{n} / \mathrm{a}$ & $\mathrm{n} / \mathrm{a}$ & n/a & n/a & $\mathrm{n} / \mathrm{a}$ & 31.5 & 21.8 & 16.2 & 19.1 & $\mathrm{n} / \mathrm{r}$ & $n / r$ \\
\hline 189 & LC-UV & n/d & $\mathrm{n} / \mathrm{d}$ & n/d & $\mathrm{n} / \mathrm{d}$ & 30.9 & 28.4 & 10.0 & 26.4 & 30.9 & 28.4 & 10.0 & 26.4 & $\mathrm{n} / \mathrm{r}$ & $\mathrm{n} / \mathrm{r}$ \\
\hline 191 & RIA & n/a & n/a & n/a & n/a & $\mathrm{n} / \mathrm{a}$ & n/a & n/a & n/a & 27.5 & 18.5 & 14.4 & 19.0 & $\mathrm{n} / \mathrm{r}$ & $\mathrm{n} / \mathrm{r}$ \\
\hline 194 & LC-MS/MS & $<7.0$ & $<7.0$ & $<7.0$ & $<7.0$ & 26.5 & 20.7 & 11.4 & 17.4 & 26.5 & 20.7 & 11.4 & 17.4 & 240.5 & 330.5 \\
\hline 195 & LC-MS/MS & n/d & n/d & n/d & $\mathrm{n} / \mathrm{d}$ & 26.3 & 18.7 & 11.8 & 18.3 & 26.3 & 18.7 & 11.8 & 18.3 & 241.0 & 333.0 \\
\hline 196 & CLIA & n/a & n/a & n/a & n/a & $\mathrm{n} / \mathrm{a}$ & $n / a$ & $\mathrm{n} / \mathrm{a}$ & $\mathrm{n} / \mathrm{a}$ & 28.0 & 18.5 & 15.3 & 19.4 & 198.6 & 298.8 \\
\hline 197 & LC-MSIMS & $<5$ & $<5$ & $<5$ & $<5$ & 28.0 & 19.0 & 14.0 & 19.0 & 28.0 & 19.0 & 14.0 & 19.0 & 234.0 & 336.0 \\
\hline 198a & LC-MS/MS & $<5.0$ & $<5.0$ & $<5.0$ & $<5.0$ & 29.9 & 20.7 & 14.4 & 20.5 & 29.9 & 20.7 & $\begin{array}{l}14.4 \\
15.2\end{array}$ & 20.5 & 207.4 & 327.1 \\
\hline $\begin{array}{c}198 b \\
199\end{array}$ & $\begin{array}{l}\text { EIA } \\
\text { LC-MS/MS }\end{array}$ & $\begin{array}{l}n / 2 \\
<2\end{array}$ & $\begin{array}{l}n / a \\
<2\end{array}$ & $\begin{array}{l}n / a \\
<2\end{array}$ & n/a & n/a & n/a & $\mathrm{n} / \mathrm{a}$ & $\begin{array}{l}\mathrm{n} / \mathrm{a} \\
187\end{array}$ & $\begin{array}{l}31.6 \\
230\end{array}$ & 20.3 & $\begin{array}{l}15.3 \\
131\end{array}$ & $\begin{array}{l}20.2 \\
107\end{array}$ & $n / r$ & $n / r$ \\
\hline $\begin{array}{l}199 \\
200\end{array}$ & LC-MS/MS & $\begin{array}{l}<2 \\
\text { n/a }\end{array}$ & $\begin{array}{l}<2 \\
\text { n/a }\end{array}$ & $<2$ & $<2$ & $\begin{array}{l}23.0 \\
0\end{array}$ & 20.2 & $\begin{array}{l}13.1 \\
0\end{array}$ & 18.7 & $\begin{array}{l}23.0 \\
258\end{array}$ & $\begin{array}{l}20.3 \\
18.9\end{array}$ & $\begin{array}{l}13.1 \\
14.6\end{array}$ & $\begin{array}{l}18.7 \\
18.8\end{array}$ & $\begin{array}{l}245.0 \\
2781\end{array}$ & $\begin{array}{r}349.0 \\
3260 .\end{array}$ \\
\hline $\begin{array}{l}200 \\
201\end{array}$ & $\begin{array}{l}\text { RAA } \\
\text { EIA }\end{array}$ & $\begin{array}{l}\text { nala } \\
\text { n/a }\end{array}$ & $\begin{array}{l}\text { nala } \\
\text { n/a }\end{array}$ & $\begin{array}{l}\text { nala } \\
\text { n/a }\end{array}$ & $\begin{array}{l}\text { nna } \\
\text { n/a }\end{array}$ & $\begin{array}{l}\mathrm{n} / \mathrm{a} \\
\mathrm{n} / \mathrm{a}\end{array}$ & $\begin{array}{l}\text { nala } \\
\text { n/a }\end{array}$ & $\begin{array}{l}\text { nala } \\
\text { n/a }\end{array}$ & $\begin{array}{l}\text { nna } \\
\text { n/a }\end{array}$ & $\begin{array}{l}25.8 \\
33.4\end{array}$ & $\begin{array}{l}18.9 \\
21.7\end{array}$ & $\begin{array}{l}14.6 \\
16.0\end{array}$ & $\begin{array}{l}18.8 \\
22.8\end{array}$ & $\begin{array}{c}2 / 8.1 \\
\mathrm{n} / \mathrm{r}\end{array}$ & $\begin{array}{c}386.9 \\
\mathrm{n} / \mathrm{r}\end{array}$ \\
\hline 202 & LC-MS/MS & $\mathrm{n} / \mathrm{d}$ & $\mathrm{n} / \mathrm{d}$ & $\mathrm{n} / \mathrm{d}$ & $\mathrm{n} / \mathrm{d}$ & 27.2 & 21.9 & 14.1 & 20.6 & 27.2 & 21.9 & 14.1 & 20.6 & 241.5 & 339.0 \\
\hline 209 & LC-MS/MS & $<1.0$ & $<1.0$ & $<1.0$ & $<1.0$ & 26.7 & 20.6 & 13.7 & 17.8 & 26.7 & 20.6 & 13.7 & 17.8 & 248.7 & 336.7 \\
\hline $210 \mathrm{a}$ & RIA & $\mathrm{n} / \mathrm{a}$ & n/a & n/a & $\mathrm{n} / \mathrm{a}$ & $\mathrm{n} / \mathrm{a}$ & n/a & n/a & n/a & 26.8 & 22.1 & 15.1 & 19.6 & 230.0 & 294.3 \\
\hline $210 \mathrm{~b}$ & CLIA & n/a & n/a & n/a & n/a & n/a & n/a & n/a & n/a & 30.4 & 18.9 & 15.1 & 20.2 & $\mathrm{n} / \mathrm{r}$ & $\mathrm{n} / \mathrm{r}$ \\
\hline 211 & LC-MS/MS & $n / d$ & $n / d$ & n/d & $\mathrm{n} / \mathrm{d}$ & 26.9 & 18.7 & 13.1 & 18.7 & 26.9 & 18.7 & 13.1 & 18.7 & 240.4 & 328.1 \\
\hline 212 & LC-MS/MS & $\mathrm{n} / \mathrm{d}$ & $<4$ & n/d & $<4$ & 30.8 & 22.8 & 14.5 & 21.0 & 30.8 & 22.8 & 14.5 & 21.0 & 231.5 & 330.9 \\
\hline 215 & LC-MSIMS & $\mathrm{n} / \mathrm{d}$ & 0.4 & $\mathrm{n} / \mathrm{d}$ & 0.4 & 24.0 & 20.0 & 12.0 & 19.6 & 24.0 & 20.4 & 12.0 & 20.0 & $n / r$ & $n / r$ \\
\hline 216 & LC-MSIMS & 0.4 & 0.7 & 0.2 & 1.0 & 33.1 & 24.9 & 17.7 & 25.7 & 33.5 & 25.6 & 17.9 & 26.7 & 258.0 & $\begin{array}{l}333.0 \\
250 .\end{array}$ \\
\hline 217 & LC-MSIMS & $<2$ & $<2$ & $<2$ & $<2$ & 24.8 & 19.6 & 13.6 & 19.2 & 24.8 & 19.6 & 13.6 & 19.2 & 233.8 & 358.1 \\
\hline $218 a$ & $\begin{array}{l}\text { CLIA } \\
\text { L-MSIMS }\end{array}$ & n/a & n/a & n/a & $\mathrm{n} / \mathrm{a}$ & $\begin{array}{l}\text { n/a } \\
272\end{array}$ & $\begin{array}{l}\text { n/a } \\
249\end{array}$ & n/a & $\begin{array}{l}\text { n/a } \\
272\end{array}$ & 26.4 & $\begin{array}{l}17.7 \\
24.9\end{array}$ & $\begin{array}{l}14.6 \\
18.3\end{array}$ & $\begin{array}{l}17.2 \\
272\end{array}$ & $n / r$ & $\begin{array}{c}n / r \\
n=320\end{array}$ \\
\hline $\begin{array}{c}128 b \\
219\end{array}$ & LC-MSIMS & $\begin{array}{l}\text { n/d } \\
<40\end{array}$ & $\begin{array}{l}\text { n/d } \\
<40\end{array}$ & $\begin{array}{l}\text { n/d } \\
<40\end{array}$ & $\begin{array}{l}\text { n/d } \\
<40\end{array}$ & $\begin{array}{l}27.2 \\
26.2\end{array}$ & $\begin{array}{l}24.9 \\
198\end{array}$ & $\begin{array}{l}18.3 \\
13.4\end{array}$ & $\begin{array}{l}2.2 \\
195\end{array}$ & $\begin{array}{l}2.2 \\
262\end{array}$ & $\begin{array}{l}24.9 \\
198\end{array}$ & $\begin{array}{l}18.3 \\
13.4\end{array}$ & $\begin{array}{l}27.2 \\
195\end{array}$ & 240.9 & 333.9 \\
\hline $\begin{array}{l}219 \\
220\end{array}$ & $\begin{array}{l}\text { LC-MSTMS } \\
\text { LC-MSMS }\end{array}$ & $\begin{array}{l}<.0 \\
<5.0\end{array}$ & $\begin{array}{l}<5.0 \\
<5.0\end{array}$ & $\begin{array}{l}<4.0 \\
<5.0\end{array}$ & $\begin{array}{l}4.0 \\
<5.0\end{array}$ & $\begin{array}{l}28.2 \\
28.0\end{array}$ & $\begin{array}{l}12.8 \\
22.0\end{array}$ & $\begin{array}{l}13.4 \\
15.0\end{array}$ & $\begin{array}{l}19.5 \\
21.0\end{array}$ & $\begin{array}{l}28.2 \\
28.0\end{array}$ & $\begin{array}{l}12.8 \\
22.0\end{array}$ & $\begin{array}{l}15.4 \\
15.0\end{array}$ & $\begin{array}{l}19.5 \\
21.0\end{array}$ & $\begin{array}{l}n / r \\
n / r\end{array}$ & $\begin{array}{l}n / r \\
n / r\end{array}$ \\
\hline $221 a$ & LC-MS/MS & $n / d$ & $n / d$ & $n / d$ & $\mathrm{n} / \mathrm{d}$ & 26.1 & 17.5 & 12.8 & 19.8 & 26.1 & 17.5 & 12.8 & 19.8 & 249.7 & 357.8 \\
\hline $221 \mathrm{~b}$ & LC-UV & $\mathrm{n} / \mathrm{d}$ & $\mathrm{n} / \mathrm{d}$ & $\mathrm{n} / \mathrm{d}$ & $\mathrm{n} / \mathrm{d}$ & 25.3 & 15.9 & 51.0 & 20.6 & 25.3 & 15.9 & 51.0 & 20.6 & $\mathrm{n} / \mathrm{r}$ & $\mathrm{n} / \mathrm{r}$ \\
\hline 223 & LC-MS/MS & $<5$ & $<5$ & $<5$ & $<5$ & 24.8 & 18.6 & 13.3 & 18.3 & 24.8 & 18.6 & 13.3 & 18.3 & 241.2 & 313.2 \\
\hline 225 & LC-MS/MS & $<5.0$ & $<5.0$ & $<5.0$ & $<5.0$ & 32.4 & 24.8 & 20.1 & 21.1 & 32.4 & 24.8 & 20.1 & 21.1 & 235.9 & 284.1 \\
\hline $228 \mathrm{a}$ & LC-MS/MS & 0.8 & 1.5 & 0.4 & 1.7 & 28.1 & 23.1 & 15.2 & 25.4 & 28.8 & 24.6 & 15.6 & 27.1 & 240.0 & 334.0 \\
\hline 231 & LC-UV & $\mathrm{n} / \mathrm{d}$ & $\mathrm{n} / \mathrm{d}$ & 33.0 & n/d & 30.6 & 20.8 & 12.7 & 21.0 & 30.6 & 20.8 & 45.7 & 21.0 & 268.7 & 287.3 \\
\hline 234 & LC-MS/MS & $<3$ & $<3$ & $<3$ & $<3$ & 25.2 & 18.9 & 13.7 & 18.0 & 25.2 & 18.9 & 13.7 & 18.0 & 246.0 & 300.0 \\
\hline 236 & CLIA & n/a & n/a & n/a & n/a & n/a & n/a & $\mathrm{n} / \mathrm{a}$ & n/a & 27.8 & 17.4 & 12.5 & 17.9 & $n / r$ & $n / r$ \\
\hline 241 & LC-MS/MS & 0.4 & 0.9 & $\mathrm{n} / \mathrm{d}$ & 0.9 & 25.4 & 18.6 & 12.5 & 18.3 & 25.8 & 19.5 & 12.5 & 19.2 & 212.0 & 302.5 \\
\hline $\begin{array}{l}242 \\
243\end{array}$ & $\begin{array}{l}\text { LC-MSMS } \\
C-\text { LY }\end{array}$ & nld & n/d & $\begin{array}{l}\text { nnd } \\
\text { nod }\end{array}$ & n/d & $\begin{array}{l}28.3 \\
28.8\end{array}$ & $\begin{array}{l}20.5 \\
21.2\end{array}$ & $\begin{array}{l}14.5 \\
14.8\end{array}$ & $\begin{array}{l}20.6 \\
21.5\end{array}$ & $\begin{array}{l}28.3 \\
288\end{array}$ & $\begin{array}{l}20.5 \\
212\end{array}$ & $\begin{array}{l}14.5 \\
14.8\end{array}$ & $\begin{array}{l}20.6 \\
215\end{array}$ & $\begin{array}{l}245.0 \\
2459\end{array}$ & $\begin{array}{l}332.0 \\
3256\end{array}$ \\
\hline $\begin{array}{l}244 \\
244\end{array}$ & LC-MSIMS & $<5$ & $<5$ & $<5$ & $<5$ & $\begin{array}{l}27.8 \\
27.0\end{array}$ & $\begin{array}{l}21.2 \\
18.0\end{array}$ & $\begin{array}{l}14.8 \\
14.0\end{array}$ & $\begin{array}{l}21.5 \\
18.0\end{array}$ & $\begin{array}{l}27.8 \\
27.0\end{array}$ & $\begin{array}{l}21.2 \\
18.0\end{array}$ & $\begin{array}{l}14.8 \\
14.0\end{array}$ & $\begin{array}{l}2.5 \\
18.0\end{array}$ & $\begin{array}{r}222.9 \\
222.0\end{array}$ & $\begin{array}{l}\begin{array}{l}250.0 \\
337.0\end{array} \\
3\end{array}$ \\
\hline 245 & LC-UV & $n / d$ & $n / d$ & $n / d$ & $n / d$ & 38.5 & 33.2 & 15.9 & 27.2 & 38.5 & 33.2 & 15.9 & 27.2 & 240.8 & 335.5 \\
\hline & plicable & noasse & ds); r & eporte & not d $\mathrm{d}>\mathrm{s}$ & $=l_{e}$ & i repor & ntitatio & & & & & & & \\
\hline & NIST Value & 0.52 & 0.81 & $<0.5$ & 0.81 & 24.8 & 18.1 & 12.4 & 18.1 & 25.3 & 18.9 & 12.4 & 18.9 & 238.6 & 334.8 \\
\hline & u & 0.17 & 0.06 & 0.00 & 0.06 & 0.8 & 0.4 & 0.3 & 0.4 & 0.8 & 0.4 & 0.3 & 0.4 & 3.9 & 5.2 \\
\hline
\end{tabular}

